\title{
Techno-Economic Assessment of IGCC Power Plants Using Gas Switching Technology to Minimize the Energy Penalty of $\mathrm{CO}_{2}$ Capture
}

\author{
Szabolcs Szima ${ }^{1} \oplus$, Carlos Arnaiz del Pozo ${ }^{2}$, Schalk Cloete ${ }^{3, *}{ }^{\circledR}$, Szabolcs Fogarasi ${ }^{1}$, Ángel Jiménez Álvaro ${ }^{2}{ }^{\circledR}$, \\ Ana-Maria Cormos ${ }^{1}$, Calin-Cristian Cormos ${ }^{1}\left(\mathbb{D}\right.$ and Shahriar Amini ${ }^{3}$ \\ 1 Faculty of Chemistry and Chemical Engineering, Babes-Bolyai University, 400028 Cluj Napoca, Romania; \\ szabolcs.szima@gmail.com (S.S.); fogarasi.szabolcs@yahoo.com (S.F.); ana.cormos@ubbcluj.ro (A.-M.C.); \\ cormos@chem.ubbcluj.ro (C.-C.C.) \\ 2 Departamento de Ingeniería Energética, Escuela Técnica Superior de Ingenieros Industriales (ETSII), \\ Universidad de Politécnica de Madrid, c/José Gutiérrez Abascal n², 28006 Madrid, Spain; \\ cr.arnaiz@upm.es (C.A.d.P.); a.jimenez@upm.es (Á.J.Á.) \\ 3 Flow Technology Group, SINTEF Industry, 7031 Trondheim, Norway; shahriar.amini@sintef.no \\ * Correspondence: schalk.cloete@sintef.no
}

\section{check for} updates

Citation: Szima, S.; Arnaiz del Pozo, C.; Cloete, S.; Fogarasi, S.; Jiménez Álvaro, Á.; Cormos, A.-M.; Cormos, C.-C.; Amini, S. Techno-Economic Assessment of IGCC Power Plants Using Gas Switching Technology to Minimize the Energy Penalty of $\mathrm{CO}_{2}$ Capture. Clean Technol. 2021, 3, 594-617. https://doi.org/10.3390/ cleantechnol3030036

Academic Editor: Diganta B. Das

Received: 27 June 2021

Accepted: 3 August 2021

Published: 10 August 2021

Publisher's Note: MDPI stays neutral with regard to jurisdictional claims in published maps and institutional affiliations.

Copyright: (c) 2021 by the authors. Licensee MDPI, Basel, Switzerland. This article is an open access article distributed under the terms and conditions of the Creative Commons Attribution (CC BY) license (https:/ / creativecommons.org/licenses/by/ $4.0 /)$.

\begin{abstract}
Cost-effective $\mathrm{CO}_{2}$ capture and storage (CCS) is critical for the rapid global decarbonization effort recommended by climate science. The increase in levelized cost of electricity (LCOE) of plants with CCS is primarily associated to the large energy penalty involved in $\mathrm{CO}_{2}$ capture. This study therefore evaluates three high-efficiency CCS concepts based on integrated gasification combined cycles (IGCC): (1) gas switching combustion (GSC), (2) GSC with added natural gas firing (GSC$\mathrm{AF}$ ) to increase the turbine inlet temperature, and (3) oxygen production pre-combustion (OPPC) that replaces the air separation unit (ASU) with more efficient gas switching oxygen production (GSOP) reactors. Relative to a supercritical pulverized coal benchmark, these options returned $\mathrm{CO}_{2}$ avoidance costs of $37.8,22.4$ and $37.5 €$ /ton (including $\mathrm{CO}_{2}$ transport and storage), respectively. Thus, despite the higher fuel cost and emissions associated with added natural gas firing, the GSC-AF configuration emerged as the most promising solution. This advantage is maintained even at $\mathrm{CO}_{2}$ prices of $100 €$ /ton, after which hydrogen firing can be used to avoid further $\mathrm{CO}_{2}$ cost escalations. The GSC-AF case also shows lower sensitivity to uncertain economic parameters such as discount rate and capacity factor, outperforms other clean energy benchmarks, offers flexibility benefits for balancing wind and solar power, and can achieve significant further performance gains from the use of more advanced gas turbine technology. Based on all these insights, the GSC-AF configuration is identified as a promising solution for further development.
\end{abstract}

Keywords: gas switching combustion; gas switching oxygen production; integrated gasification combined cycle; chemical looping combustion; CCS

\section{Introduction}

The global power sector faces a key challenge in the 21st century: achieving rapid emissions reductions despite strong demand growth [1]. The target set at the Paris Climate Agreement [2] is to limit the global average temperature increase to "well below $2{ }^{\circ} \mathrm{C}^{\prime \prime}$ by the end of the century. The models presented by the Intergovernmental Panel on Climate Change (IPCC) requires zero or even negative emissions from the power sector to comply with the $2{ }^{\circ} \mathrm{C}$ target [3].

Several options are available to reduce $\mathrm{CO}_{2}$ emissions depending on the source of origin, including energy efficiency, renewable energy, nuclear energy, fuel switching, and $\mathrm{CO}_{2}$ capture and storage (CCS). Among these pathways, CCS is arguably the most promising for drastic emissions reduction for three main reasons: (1) CCS retrofits can achieve emissions reductions from plants that have already been built, (2) CCS can be 
applied to sectors other than electricity such as direct industrial emissions or clean fuels, and (3) CCS can achieve negative emissions through BECCS or direct air capture. Unfortunately, the deployment of CCS is lagging far behind the trajectory required by the Paris Climate Accord [4], mostly because of economic and political challenges. Capturing and storing $\mathrm{CO}_{2}$ will always be more expensive than simply emitting it to the atmosphere, and, to date, there have been limited policy incentives for covering these added costs.

However, the added cost of CCS can be minimized through more advanced $\mathrm{CO}_{2}$ capture processes. Lowering the energy demand for the $\mathrm{CO}_{2}$ separation process presents one promising pathway towards lower operating and capital costs of CCS plants. In the case of power production from solid fuels, the integration of a chemical looping combustion (CLC) $[5,6]$ unit in an integrated gasification combined cycle (IGCC) system offers a promising pathway to a lower energy penalty [7]. In the IGCC system, the fuel is gasified and burned in a combined cycle gas turbine for power production. In general, the net electric efficiency of an IGCC power plant is around $47 \%$ without capture, whereas, if the conventional pre-combustion $\mathrm{CO}_{2}$ capture is added, the efficiency drops as low as $36 \%$ [8]. This substantial energy penalty presents the major obstacle to CCS deployment.

CLC offers a way to substantially reduce this energy penalty, leading to considerable reductions in the $\mathrm{CO}_{2}$ avoidance cost [9]. The CLC process relies on the basic idea of supplying oxygen in the combustion media via a solid oxygen carrier, as presented in Figure 1 (left). Oxygen is separated from air in the air reactor and transported to the fuel reactor via the OC, where it reacts with the fuel. Combustion occurs in a nitrogen-free zone, thus requiring only water condensation for delivering a high-purity $\mathrm{CO}_{2}$ stream. Spallina et al. [10] compared the performance of several packed bed CLC-IGCC power plant strategies, obtaining an electrical efficiency of $41 \%$, lowering the energy penalty relative to a pre-combustion capture benchmark with 5.7\%-points. Hamers et al. [11] compared the performance of packed and fluidized bed reactors in CLC-IGCC systems but found no significant effect on the efficiency of the plant. In this case, net efficiency as high as $42 \%$ was obtained, further reducing the energy penalty with $6.92 \%$ points relative to pre-combustion. Cloete et al. [12] replaced the air separation unit within the IGCC plant with a chemical looping oxygen production unit reducing the energy penalty by $8.1 \%$-points for an efficiency of $43.4 \%$ and reaching $45.4 \%$ if hot gas clean-up technology is employed.
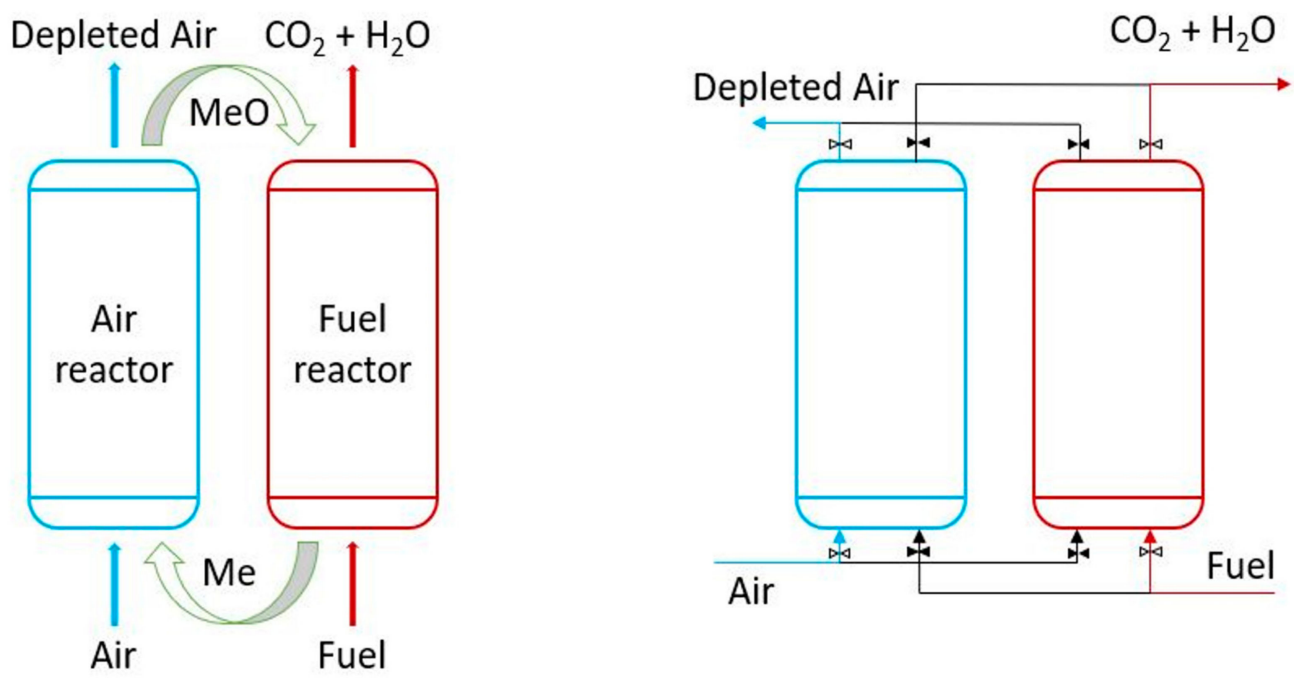

Figure 1. The chemical looping combustion process (left) and the gas switching combustion variant (right) that was investigated in this study.

Alternatively, a 3-step chemical looping combustion configuration can be employed where an extra reactor is used to partially oxidize an iron-based oxygen carrier using steam to produce hydrogen for driving a combined cycle. Sorgenfrei et al. [13] present the design 
and evaluation of a CLC IGCC system based on this configuration, achieving a net electric efficiency of $44.8 \%$ using a British Gas/Lurgi gasifier. Wu et al. [14] evaluated a similar configuration to obtain net efficiencies as high as $45.6 \%$. This three-step configuration achieves efficiency benefits because the hydrogen firing can achieve considerably higher turbine inlet temperatures (TIT) than the hot depleted air stream from the conventional CLC configuration. However, the extra reactor makes the configuration considerably more complex than conventional two-reactor CLC, and equilibrium limitations enforce the use of moving beds, adding further complexity and increasing reactor size.

One important challenge with CLC is scale-up under pressurized conditions. To overcome this challenge, gas switching combustion (GSC) [15] was proposed. As shown in Figure 1 (right), the GSC concept keeps the solid OC in a single reactor where it is alternately oxidized with air and reduced by the fuel. The alternating feed gas streams are fed to the reactor using inlet switching valves. Similar switching valves are needed at the reactor outlet to separate the alternating depleted air and $\mathrm{CO}_{2}$ streams emerging from each gas switching reactor. Such a simple standalone bubbling fluidized bed reactor promises to be substantially easier to scale up and pressurize than the interconnected dual circulating fluidized bed CLC configuration. To maintain continuous operation, a coordinated cluster of several dynamically operated GSC reactors can be used. Figure 1 (right) illustrates a simple cluster of two reactors where the reactor on the left is being oxidized and the one on the right is being reduced. When the desired degree of oxygen carrier conversion is achieved, the feed valves will switch to start reducing the reactor on the left and oxidizing the one on the right. A cluster of only two reactors is shown here for simplicity, but, since the air flowrate is much larger than the fuel flowrate, it is necessary to split the air feed between a larger number of reactors to maintain a similar fluidization velocity in all reactors [16].

The GSC-IGCC configuration was recently investigated with the aim of maximizing the process efficiency by circumventing two main efficiency challenges [17]. First, an additional combustor fired by natural gas was added after the GSC reactors to increase the TIT, thereby increasing the power cycle efficiency. Second, a recuperator was implemented to recover heat from the reduction outlet gases and transfer this thermal energy through the topping power cycle for more efficient electricity production. In addition, the condensation enthalpy in the steam originating from fuel combustion could be partially recovered at suitable temperatures in the steam cycle due to the high pressure of the GSC reduction outlet gases. Combined, these features succeeded in eliminating the energy penalty of $\mathrm{CO}_{2}$ capture from an IGCC power plant, reaching efficiencies as high as 50\%.

A major contributor to auxiliary consumption in an IGCC power plant is the air separation unit (ASU), the unit providing the necessary oxygen for the gasification of the fuel. The chemical looping process can be successfully applied for the separation of oxygen from the other constituents of air [18] using several metal oxides. Shi et al. [19] investigated several chemical looping air separation layouts, both continuous and batch types, and concluded that batch operation is more cost-effective for oxygen production. Deng et al. [20] modelled a chemical looping air separation unit using a fluidized bed reactor and optimized the process. A gas switching variant of this principle, called gas switching oxygen production (GSOP), was recently proposed to displace the ASU in a precombustion $\mathrm{CO}_{2}$ capture IGCC configuration [21]. This oxygen production pre-combustion (OPPC) plant could achieve a net efficiency of more than $45 \%$, albeit with a somewhat lower $\mathrm{CO}_{2}$ avoidance of around $80 \%$. Another benefit is that the relatively low operating temperature of the GSOP reactors will circumvent possible technical challenges with downstream valves and filters after GSC reactors.

The present study will investigate the effects of these large efficiency gains from an economic point of view. For the GSC configuration with added natural gas firing, greater efficiency will decrease levelized costs related to coal fuel and $\mathrm{CO}_{2}$ transport and storage. Extracting more power from the syngas by means of a higher TIT will also substantially reduce the levelized costs of the expensive gasification train (coal and ash handling, gasifier, 
air separation unit, and gas clean-up). On the other hand, the use of natural gas for added firing will increase fuel costs because natural gas is more expensive than coal and reduce $\mathrm{CO}_{2}$ avoidance because the $\mathrm{CO}_{2}$ from natural gas combustion is not captured. For the OPPC configuration, levelized cost reductions can also be expected due to the high efficiency, but the relatively diluted syngas produced by this configuration will substantially increase the capital cost of the gasifier and gas clean-up units.

To quantify these trade-offs, this study presents a bottom-up economic assessment of GSC-IGCC plants with and without added natural gas firing and the OPPC plant. These results are compared to several benchmarks, including IGCC plants with and without conventional pre-combustion $\mathrm{CO}_{2}$ capture. The plant performance will be quantified in terms of the levelized cost of electricity and $\mathrm{CO}_{2}$ avoidance cost, relative to the IGCC and supercritical pulverized coal plant without $\mathrm{CO}_{2}$ capture. In addition, the sensitivity of these performance measures to key economic assumptions such as fuel costs and discount rate will be identified. Finally, the economic performance of these advanced IGCC plants will be benchmarked against other clean energy technologies, including nuclear, wind, and solar PV, in a future energy system with high $\mathrm{CO}_{2}$ prices.

\section{Methodology}

In this paper, five coal-fired IGCC power plant layouts are compared from a technoeconomic point of view:

- $\quad$ Case 1: IGCC power plant without $\mathrm{CO}_{2}$ capture (IGCC);

- $\quad$ Case 2: IGCC power plant with pre-combustion $\mathrm{CO}_{2}$ capture using Selexol ${ }^{\mathrm{TM}}$ liquidgas absorption (IGCC-PCC);

- $\quad$ Case 3: GSC-IGCC power plant with inherent $\mathrm{CO}_{2}$ capture (GSC);

- Case 4: GSC-IGCC power plant with added natural gas firing (GSC-AF);

- $\quad$ Case 5: GSOP-IGCC power plant with pre-combustion $\mathrm{CO}_{2}$ capture using Selexol ${ }^{\mathrm{TM}}$ liquid-gas absorption (OPPC).

The results are also compared to a supercritical pulverized coal power plant [8] as this technology is widely deployed in the power sector today. Simplified schematics of the power plants for Cases 3, 4, and 5 are shown in Figures 2-4, respectively. More detailed schematics can be found in previously published technical assessments [17,21]. The most important differences between the GSC (Figure 2) and GSC-AF (Figure 3) plants are (1) the GSC-AF plant fires natural gas after the GSC oxidation step to increase the TIT, and (2) the GSC-AF plant transfers heat from the $\mathrm{CO}_{2}$ rich reduction step outlet gases to the compressed air stream using a recuperator. In contrast, the GSC plant must use the relatively high-grade heat in the GSC reduction step outlet gases to superheat steam for the bottoming cycle because insufficient high-grade heat is available from the gas turbine outlet gases, resulting from the lower GT firing temperature.

The OPPC plant (Figure 4) does not use GSC reactors, relying on a conventional pre-combustion $\mathrm{CO}_{2}$ capture train to separate $\mathrm{CO}_{2}$. However, large efficiency gains are achieved by using GSOP reactors to produce an $\mathrm{N}_{2}$-free oxidant stream $\left(17 \% \mathrm{~mol}\right.$ of $\left.\mathrm{O}_{2}\right)$ for the gasifier and pre-heating the air to $900{ }^{\circ} \mathrm{C}$. In this way, the OPPC plant avoids the energy penalty of an ASU and greatly reduces the amount of $\mathrm{H}_{2}$ required (and the associated steam consumption) to reach the desired TIT relative to a conventional pre-combustion plant. The process flowsheets of the reference plants (Cases $1 \& 2$ ) are similar to the layouts shown in Gazzani et al. [22]. 


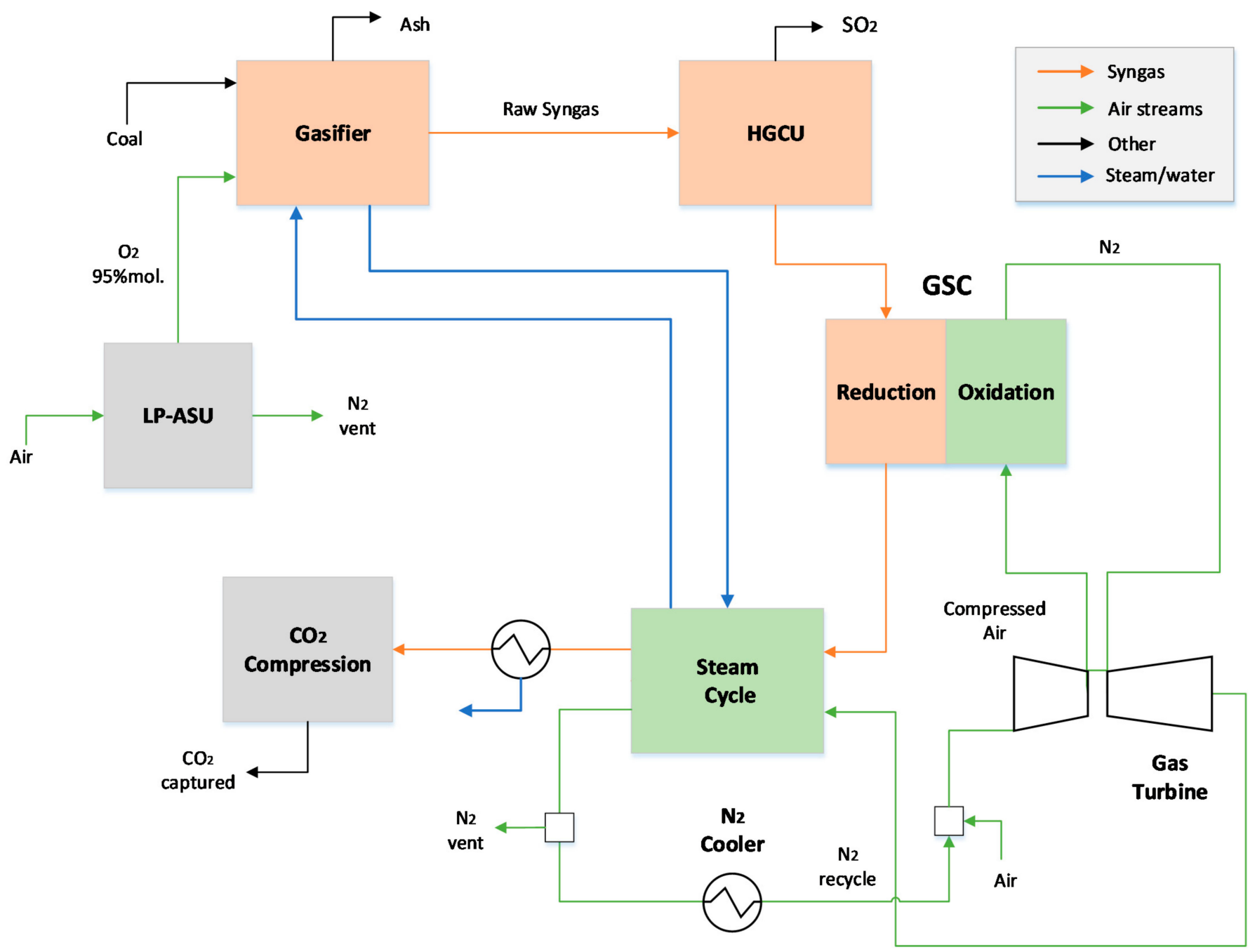

Figure 2. Schematic of the GSC power plant (Case 3) [17].

\subsection{Process Simulation}

Two benchmark IGCC plants are considered in this work: the unabated IGCC model (Case 1) consists of a dry fed entrained flow gasifier (Shell Type), syngas scrubbing, and heat recovery with cold gas desulphurization unit. $\mathrm{O}_{2}$ is delivered by a high-pressure air separation unit, and coal is loaded with high purity $\mathrm{N}_{2}$. The ASU is $50 \%$ integrated with the gas turbine compressor, while all available $\mathrm{N}_{2}$ is mixed with the syngas fuel to minimize NOx emissions for complying with regulations. The power island assumptions considered in this work are similar to the ones in Spallina et al. [10], assuming an F-class turbine adapted to operate with syngas instead of natural gas.

The pre-combustion $\mathrm{CO}_{2}$ capture model (Case 2) has a similar setup to the unabated IGCC plant, but a low-pressure ASU is used instead (no integration is advised for $\mathrm{H}_{2}$ co-production and reliability), while coal is loaded with $\mathrm{CO}_{2}$, resulting in slightly higher cold gas efficiency. After syngas scrubbing and steam addition from the HP stage steam turbine outlet (reaching a steam to $\mathrm{CO}$ ratio of 1.9 to avoid catalyst deterioration), the water-gas shift (WGS) reaction is carried out in two intercooled adiabatic reactors. $\mathrm{CO}_{2}$ is removed with Selexol ${ }^{\mathrm{TM}}$ absorption, modelled based on the work of Kapetaki [23] for component solubility, and compressed in a five-stage intercooled compressor. $\mathrm{H}_{2}$-rich fuel is saturated and mixed with $\mathrm{N}_{2}$ from the ASU for NOx abatement and fired in the gas turbine (GT). 


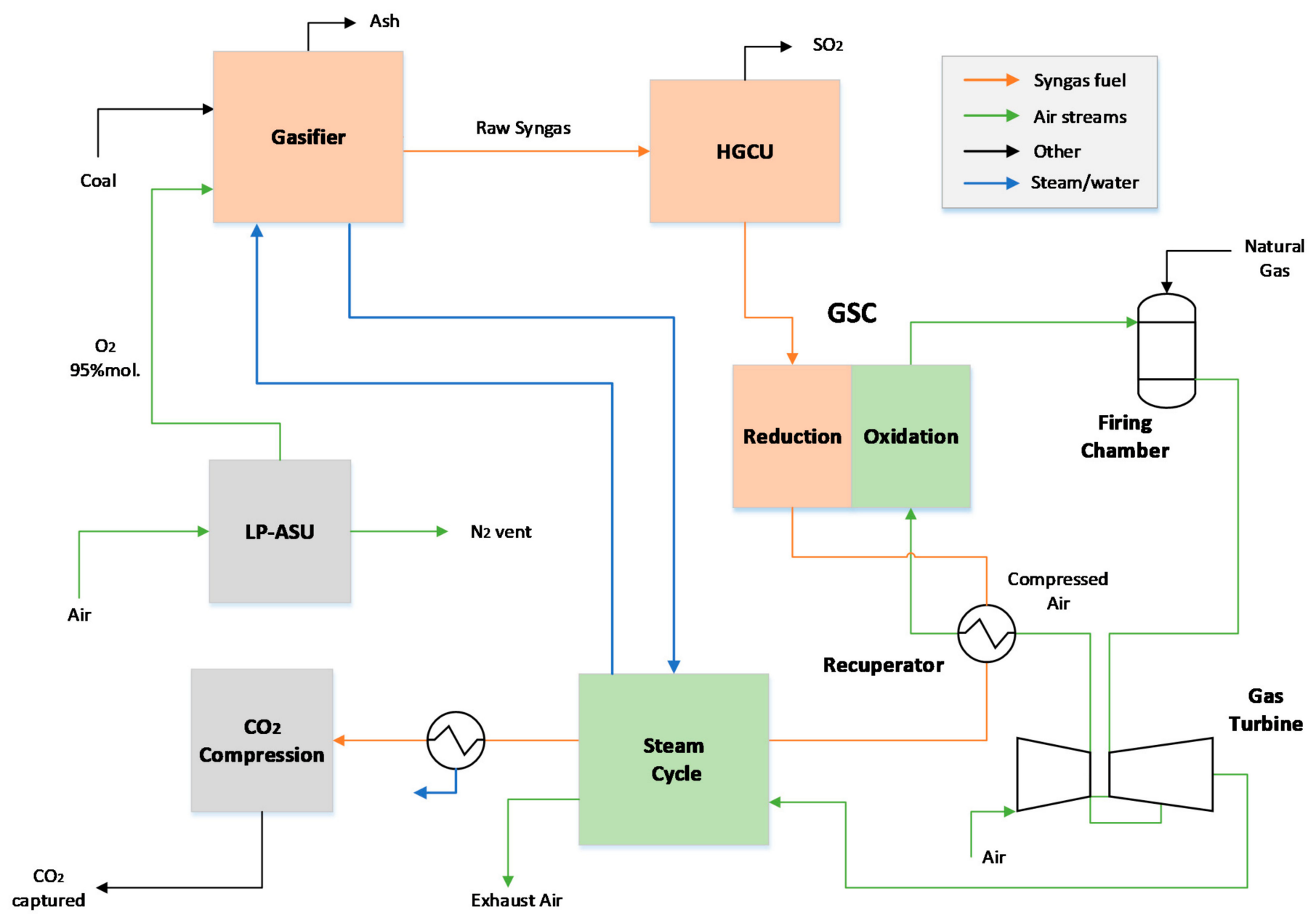

Figure 3. Schematic of GSC+AF power plant (Case 4) [17].

The GSC plants (Cases 3 and 4) are modelled with a similar approach as in Arnaiz del Pozo et al. [17], with the notable difference of employing an $\mathrm{NiO}$ oxygen carrier instead of Ilmenite, which shows higher feasibility to operate under the assumed maximum temperatures $\left(1200{ }^{\circ} \mathrm{C}\right)[24]$ and has a better performance in terms of undesired mixing, achieving higher capture ratios due to the higher oxygen carrying capacity that facilitates longer reactor cycles. The same component efficiencies for the power island are taken and, considering the reduced turbine inlet temperature resulting from the mechanical limits of the oxygen carrier, a simple correlation by Horlock [25] is taken to determine stator cooling, neglecting cooling of the rotor (Case 3). For the GSC plant with natural gas extra firing, the plant simulations performed in the present study consider a GT cooling flow model resulting a small decrease in efficiency, a lower capture rate, and a higher heat input provided by the extra natural gas relative to the results reported in Arnaiz del Pozo et al. [17] (Case 4). The latter study reveals that carrying out extra firing with a portion of syngas results in significantly lower (more than 15\%-points below) carbon capture relative to natural gas, because of its larger carbon intensity, while lower electrical efficiency is attained, due to thermal losses of syngas production and treating, which curtails the attractiveness of this option. Similar to the benchmark IGCC plants, the configurations integrating GSC technology produce syngas with a Shell gasifier, but also include hot has desulphurization as an additional efficiency enhancement. 


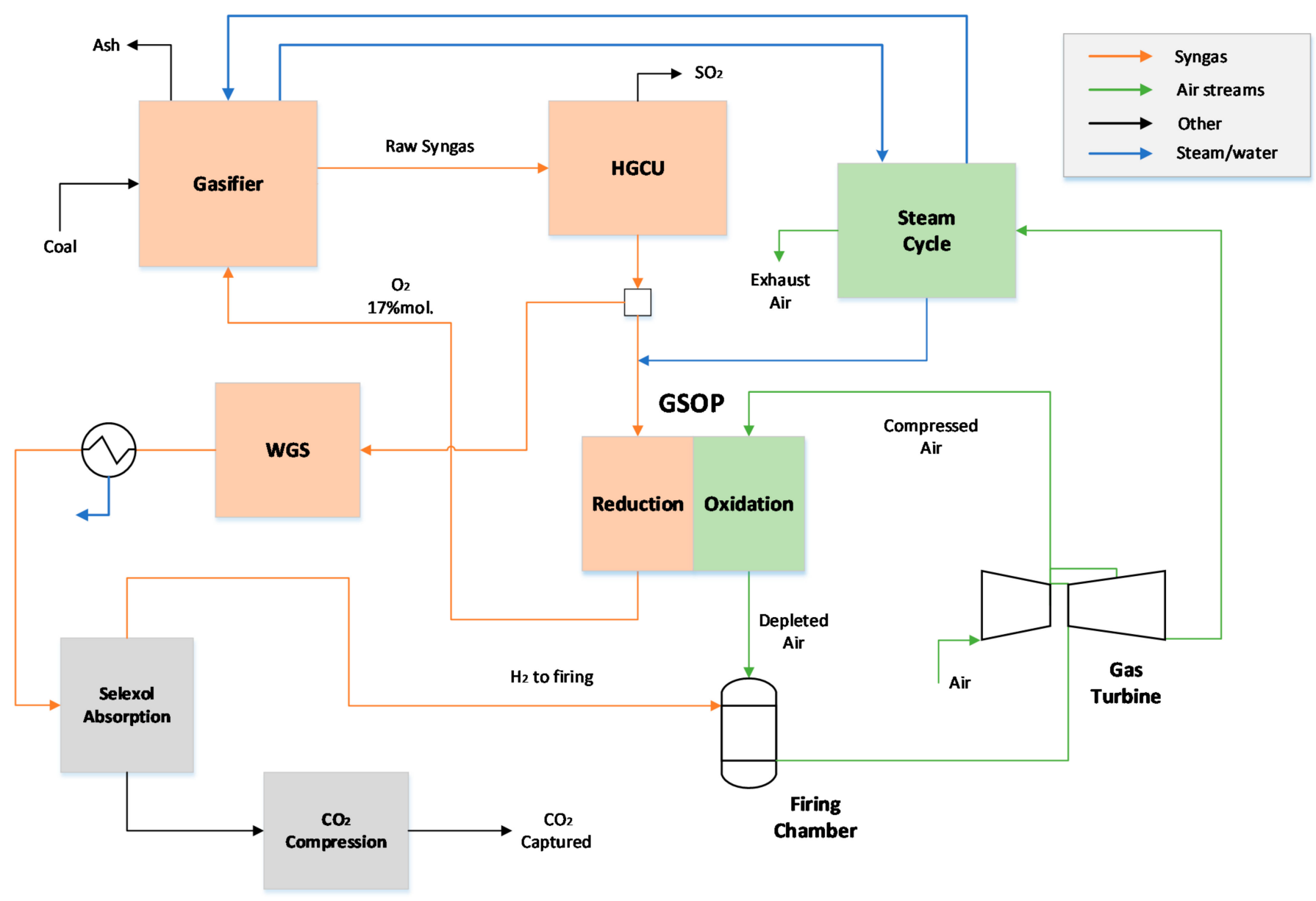

Figure 4. Schematic of the OPPC power plant (Case 5) [21].

The OPPC plant presented here (Case 5) has a similar configuration to the one shown in Arnaiz del Pozo et al. [21], where a GSOP cluster delivers an oxidant stream to a Winkler gasifier to produce syngas. After hot gas desulphurization and contaminant removal, a portion of the syngas, together with some intermediate pressure steam from the bottoming cycle, is routed to the GSOP cluster. The remaining syngas is sent to a WGS unit similarly to the pre-combustion capture model. Subsequent $\mathrm{CO}_{2}$ sequestration is performed with a simplified Selexol ${ }^{\mathrm{TM}}$ unit (as $\mathrm{H}_{2} \mathrm{~S}$ has already been removed). The compressed air is firstly heated in the GSOP oxidation stage to $900{ }^{\circ} \mathrm{C}$, and then it enters an extra firing chamber to reach higher temperatures by combustion of the $\mathrm{H}_{2}$-rich fuel produced in the WGS unit. When incorporating the coolant flows in the GT model, a smaller portion of air passes through the GSOP cluster relative to Arnaiz del Pozo et al. [21] and, in parallel, a larger fraction of syngas must be sent to the WGS unit to generate sufficient $\mathrm{H}_{2}$ to reach the required combustor outlet temperature (COT).

The calibrated natural gas-fired turbine has a COT of $1440{ }^{\circ} \mathrm{C}$ and a TIT of $1360{ }^{\circ} \mathrm{C}$ with a turbine outlet temperature of $603{ }^{\circ} \mathrm{C}$, operating with a pressure ratio of 18.1 and a simple cycle efficiency of $39 \%$. When applied to the syngas fired models, it is assumed that the turbine operates at its nominal design point (equal pressure ratio and polytropic efficiencies of compressor and expansion stages) and that the cooling flows are adjusted to operate at the same TIT with the same cooling fraction to the rotor. This assumes a higher level of blade cooling technology and an appropriate compressor design to account for the higher flow rate of lower energy density fuel relative to the natural gas case. Furthermore, the coal flow rate to the plant is fixed, resulting in a different size of the GT for each case. This is consistent with the fact that the gasification island is the major cost component of the plant, with a constant heat input for all cases, and since GSC technology has a long 
deployment horizon, it is safe to assume some flexibility in GT design. The steam cycle consists of a three-pressure level with a reheat heat recovery steam generator (HRSG).

For NOx control, a large amount of $\mathrm{N}_{2}$ from the ASU is mixed with the fuel in the IGCC-PCC case, while the GSC case requires no special measures due to the flameless combustion in the GSC reactors. For the GSC-AF case, it is assumed that the spontaneous combustion of natural gas in the hot depleted air stream from the GSC reactors can be carried out in a manner approaching the behavior of a premixed combustor by employing many fuel injectors and high turbulence [26]. A similar approach is followed in the OPPC case.

The power plant models were built with the process simulator Unisim Design R451 using the Peng Robinson equation of state and the ASME steam tables for thermodynamic property calculations. Detailed modelling assumptions of the plant units are provided in the Appendix A. The time-averaged operating points of the gas switching reactors as input for the power plant were determined with a transient 0-D model in Matlab, described in more detail in the technical assessments of the GSC and GSC-AF plants [17] and the OPPC plant [21]. This model assumes ideal gas behavior of the gaseous species, which is acceptable due to the high temperature and relatively low-pressure values encountered in the reactors. The reactions included in the models for the GSC (Equations (1)-(4)) and GSOP (Equations (5)-(8)) processes are summarized below. Equations (1)-(7) are assumed to proceed to completion, whereas Equation (8) is assumed to reach equilibrium as defined in Arnaiz del Pozo et al. [21]:

$$
\begin{gathered}
\mathrm{CH}_{4}+4 \mathrm{NiO} \rightarrow 4 \mathrm{Ni}+\mathrm{CO}_{2}+2 \mathrm{H}_{2} \mathrm{O} \\
\mathrm{H}_{2}+\mathrm{NiO} \rightarrow \mathrm{Ni}+\mathrm{H}_{2} \mathrm{O} \\
\mathrm{CO}+\mathrm{NiO} \rightarrow \mathrm{Ni}+\mathrm{CO}_{2} \\
\mathrm{O}_{2}+2 \mathrm{Ni} \rightarrow 2 \mathrm{NiO} \\
\mathrm{CH}_{4}+8 \mathrm{Ca}_{2} \mathrm{AlMnO}_{5.5} \rightarrow 8 \mathrm{Ca}_{2} \mathrm{AlMnO}_{5}+\mathrm{CO}_{2}+2 \mathrm{H}_{2} \mathrm{O} \\
\mathrm{H}_{2}+2 \mathrm{Ca}_{2} \mathrm{AlMnO}_{5.5} \rightarrow 2 \mathrm{Ca}_{2} \mathrm{AlMnO}_{5}+\mathrm{H}_{2} \mathrm{O} \\
\mathrm{CO}+2 \mathrm{Ca}_{2} \mathrm{AlMnO}_{5.5} \rightarrow 2 \mathrm{Ca}_{2} \mathrm{AlMnO}_{5}+\mathrm{CO}_{2} \\
\mathrm{O}_{2}+4 \mathrm{Ca}_{2} \mathrm{AlMnO}_{5} \leftrightarrow 4 \mathrm{Ca}_{2} \mathrm{AlMnO}_{5.5}
\end{gathered}
$$

\subsection{Economic Assessment}

The economic assessment methodology is presented in four parts: (1) the design and cost assessment of gas switching reactors and heat exchangers, (2) other capital cost assumptions, (3) operating and maintenance cost assumptions, and (4) the methodology for calculating the levelized cost of electricity and the cost of $\mathrm{CO}_{2}$ avoidance.

\subsubsection{Reactor and Heat Exchanger Design}

The reactor cost was estimated by assuming the wall structure presented in Figure 5 where, from left to right, the layers represent the inner Ni-alloy to withstand the temperature, corrosion and abrasion loads, the middle $0.54 \mathrm{~m}$ thick layer of thermal insulation for an outer wall temperature of $80^{\circ} \mathrm{C}$, and the outer carbon steel shell to carry the pressure load. The cost of the reactor strongly depends on the cost of the shell, which depends on the insulation thickness employed. This is investigated in a sensitivity analysis in the results section. Each reactor was assumed to consist of two process vessels: an inner Ni-alloy vessel and an outer carbon steel vessel. The fully installed cost of these vessels is estimated using the correlations given by Turton [27], with the cost of the inner vessel being doubled to account for elements such as the gas distributor and downstream particle filters. However, the cost of high-temperature outlet valves is included following Hamers et al. [11]. The cost of the initial load of OC is added to the capital cost of the reactor. 
The fluidization velocity in the reactor is assumed to be $1 \mathrm{~m} / \mathrm{s}$, which will be on the upper edge of the bubbling fluidization regime (shortly before the transition to turbulent fluidization) when $150 \mu \mathrm{m}$ particles are used according to the correlations of Bi and Grace [28]. This assumed fluidization velocity requires the total cross-sectional area of all the reactors to be $191.5 \mathrm{~m}^{2}$. The reactors in the cluster are $1.84 \mathrm{~m}$ in diameter, $3.68 \mathrm{~m}$ in height, and a total number of 72. Costs are updated for the year 2018 using the Chemical Engineering Plant Cost Index [29].

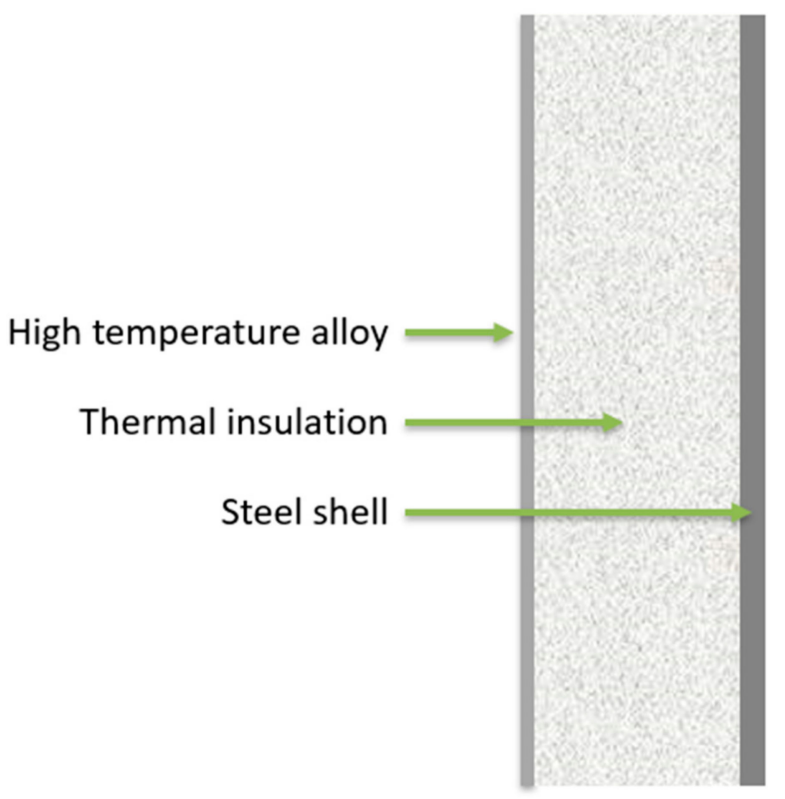

Figure 5. Assumed reactor wall structure.

For the GSOP reactors, a similar methodology is applied as in the case of the GSC reactors with the following differences: the required cross-section of the reactors is $105.4 \mathrm{~m}^{2}$, the height is $3.66 \mathrm{~m}$, the diameter is $1.83 \mathrm{~m}$, and the number of units is 40 to maintain the desired fluidization velocity of $1 \mathrm{~m} / \mathrm{s}$. Since the GSOP reactors operate at a considerably lower temperature than the GSC reactors, a thinner insulation layer of $0.31 \mathrm{~m}$ could be used to maintain the outer wall temperature of $80^{\circ} \mathrm{C}$.

The cost estimation methodology for the heat exchangers involved a similar methodology. Shell-and-tube heat exchangers are selected with stainless steel used for both the shell and the tubes. Information about the heat transfer duty and log mean temperature difference from the process simulation is combined with calculated film and overall heat transfer coefficients necessary to determine the heat transfer area required in each heat exchanger. This heat transfer area is then used in the cost functions presented in Turton [27]. The overall heat transfer coefficient is calculated as a function of film coefficients of the cold and hot streams using Nusselt number correlations from the literature [30].

\subsubsection{Capital Cost Estimation}

Capital costs are estimated using the costs from Franco et al. [8] and scaled to a chosen modeling parameter as presented in the general form of the cost (Equation (9)). $C_{0}$ and $Q_{0}$ are the reference cost and capacity of the unit, and $M$ is an exponent that depends on the equipment type. The parameters for the cost calculation are presented in Tables 1 and 2 for the cases without $\mathrm{CO}_{2}$ capture and with $\mathrm{CO}_{2}$ capture, respectively. The obtained capital cost is updated using the Chemical Engineering Plant Cost Index [29] for the year 2018:

$$
C=C_{0} *\left(\frac{Q}{Q_{0}}\right)^{M}
$$


Table 1. Reference costs, capacities and scaling exponents for the case without $\mathrm{CO}_{2}$ capture used in Equation (9).

\begin{tabular}{|c|c|c|c|c|c|c|}
\hline Equipment & Scaling Parameter & Reference Cost (M€) & Reference Capacity & Scaling Exponent & Year & Ref. \\
\hline ASU & Oxygen produced $[\mathrm{kg} / \mathrm{s}]$ & 64.48 & 26.54 & 0.67 & 2011 & [8] \\
\hline Coal handling & Coal input $[\mathrm{kg} / \mathrm{s}]$ & 49.50 & 32.90 & 0.67 & 2011 & [8] \\
\hline Ash handling & Ash flowrate $[\mathrm{kg} / \mathrm{s}]$ & 16.00 & 4.65 & 0.60 & 2011 & [8] \\
\hline HRSG & ST gross power [MW] & 35.46 & 182.36 & 0.67 & 2011 & [8] \\
\hline Gas turbine & Net power output [MW] & 88.60 & 254.42 & 1 & 2011 & [8] \\
\hline Steam turbine & ST gross power [MW] & 55.00 & 182.36 & 0.67 & 2011 & [8] \\
\hline Condenser & ST gross power $[\mathrm{MW}]$ & 40.56 & 182.36 & 0.67 & 2011 & [8] \\
\hline Gasifier & Coal thermal input [MW] & 162.00 & 828.02 & 0.67 & 2011 & [8] \\
\hline Gas clean-up & Syngas flowrate $[\mathrm{kg} / \mathrm{s}]$ & 58.03 & 75.26 & 0.67 & 2011 & [8] \\
\hline
\end{tabular}

The capital cost estimation for the base case IGCC power plant without $\mathrm{CO}_{2}$ capture is performed using the reference data presented in Table 1 and applied in Equation (9).

The capital cost estimations of Cases 2-5 are performed using the parameters presented in Table 2. Case 2 involves standard technologies for gas clean-up, whereas the other three cases use hot gas clean-up as this offers significant efficiency improvements for IGCC systems [31]. The standard gas clean-up is assumed to consist of the following units: acid-gas removal, gas cleaning, water treatment, and the Claus burner. The cost correlation parameters for the hot gas clean-up are obtained as $75 \%$ of the standard gas clean-up unit presented by Franco et al. [8] as estimated from an RTI report [32]. The cost of the WGS unit used in Cases 2 and 5 is obtained from the work of Spallina et al. [33]. All other costs are taken from Franco et al. [8]. A scaling exponent of 1 was employed for the $\mathrm{CO}_{2}$ compression because the lower costs for the cases with GSC that generate already pressurized $\mathrm{CO}_{2}$ streams stem from fewer compression stages and not from smaller compressors.

Table 2. Reference costs, capacities and scaling exponents for the cases with $\mathrm{CO}_{2}$ capture used in Equation (9).

\begin{tabular}{|c|c|c|c|c|c|c|}
\hline Equipment & Scaling Parameter & Reference Cost $(\mathrm{M} €)$ & Reference Capacity & Scaling Exponent & Year & Ref. \\
\hline ASU & Oxygen produced $[\mathrm{kg} / \mathrm{s}]$ & 72.80 & 31.45 & 0.67 & 2011 & [8] \\
\hline Coal handling & Coal input $[\mathrm{kg} / \mathrm{s}]$ & 53.89 & 38.72 & 0.67 & 2011 & [8] \\
\hline Ash handling & Ash flowrate $[\mathrm{kg} / \mathrm{s}]$ & 17.42 & 5.48 & 0.67 & 2011 & [8] \\
\hline HRSG & ST gross power [MW] & 34.10 & 168.46 & 0.67 & 2011 & [8] \\
\hline Gas turbine & Net power output [MW] & 93.32 & 282.87 & 1 & 2011 & [8] \\
\hline Steam turbine & ST gross power [MW] & 52.00 & 168.46 & 0.67 & 2011 & [8] \\
\hline Condenser & ST gross power [MW] & 39.00 & 168.46 & 0.67 & 2011 & [8] \\
\hline Gasifier & Thermal input [MW] & 180.00 & 954.08 & 0.67 & 2011 & [8] \\
\hline $\begin{array}{c}\text { Gasifier for Case } \\
5\end{array}$ & Raw syngas flowrate $[\mathrm{kg} / \mathrm{s}]$ & 167.1 & 65.60 & 0.67 & 2011 & [8] \\
\hline Gas clean-up & Syngas flowrate $[\mathrm{kg} / \mathrm{s}]$ & 61.49 & 89.21 & 0.67 & 2011 & [8] \\
\hline Hot gas clean-up & Syngas flowrate $[\mathrm{kg} / \mathrm{s}]$ & 46.12 & 89.21 & 0.67 & 2011 & [8] \\
\hline $\begin{array}{l}\text { Selexol }{ }^{\mathrm{TM}} \mathrm{CO}_{2} \\
\text { capture unit }\end{array}$ & $\begin{array}{l}\text { Shifted syngas flowrate } \\
{[\mathrm{kg} / \mathrm{s}]}\end{array}$ & 45.00 & 111.04 & 0.67 & 2011 & [8] \\
\hline WGS unit & Syngas flowrate $[\mathrm{kg} / \mathrm{s}]$ & 21.12 & 89.21 & 0.67 & 2011 & [33] \\
\hline $\mathrm{CO}_{2}$ compression & Compressor power [MW] & 30.00 & 20.69 & 1 & 2011 & {$[8]$} \\
\hline
\end{tabular}

One important uncertainty is the gasifier cost assessment for Case 5. First, a different gasification technology is used (fluidized bed in Case 5 vs. entrained flow in the other cases). Second, the produced syngas has a much lower heating value, because the $\mathrm{O}_{2}$ diluted oxidant stream $(17 \% \mathrm{~mol})$ from the GSOP employed for gasification, resulting in more than double the raw syngas flowrate relative to the other cases. This higher syngas flowrate can be expected to increase the required gasifier cross-sectional area, but it is also reasonable to expect that the gasification reactions will proceed faster due to the high concentration of $\mathrm{CO}_{2}$ and $\mathrm{H}_{2} \mathrm{O}$ in the oxidant stream and the high temperature at which this stream enters the gasifier, thus mitigating the required gasifier volume increase. In addition, elements like lock hoppers will be cheaper because the coal feed rate is the same, but the gasifier operating pressure is lower. To account for these conflicting effects, two scaling parameters were used for the gasifier cost: (1) the thermal input like the other cases and (2) the raw syngas flowrate that resulted in a much higher cost. In Table 2, scaling 
with the raw syngas flowrate (before water addition in the scrubber) is done from the reference cost of the gasifier in the pre-combustion plant in this study, which is slightly smaller than the one in Franco et al. [8]. The gasifier cost was then taken as the average of these two cost estimations. The effect of this uncertainty on the LCOE will be quantified in the results section.

The total investment cost was calculated as outlined in Table 3. A process contingency of $30 \%$ was added to the GSC reactor cluster due to its low level of technological maturity, while a $10 \%$ contingency was added to the hot gas clean-up unit which is near commercial readiness [34]. A project contingency of $18 \%$ and owner's cost of $12 \%$ are applied in line with our previous work [9]. These relatively high values are assumed to account for the technological uncertainty involved in IGCC technology.

Table 3. Estimation methodology for the total overnight cost of the plant.

\begin{tabular}{cc}
\hline Component & Definition \\
\hline Total install cost (TIC) & Installed cost of each unit \\
Process contingency (PS) & $30 \%$ of install cost for GSC reactors \\
Engineering procurement and construction costs (EPCC) & $10 \%$ of install cost for the hot gas clean-up \\
Project contingency (PT) & $14 \%$ of (TIC + PS) \\
Total plant costs (TPC) & $18 \%$ of (TIC + PS + EPCC) \\
Owners cost & TIC + PS + EPCC + PT \\
Total overnight costs & $12 \%$ of TPC \\
\hline
\end{tabular}

\subsubsection{Operating and Maintenance Costs}

Table 4 presents the assumptions for the fixed and variable operating and maintenance $(\mathrm{O} \& \mathrm{M})$ costs used in every case. The operating labour cost is included in the maintenance cost, according to Franco et al. [8], in both without and with carbon capture cases. The maintenance cost is estimated based on the gross power output of the plant. References are provided in the table for the estimations, and the fuel costs are varied in a sensitivity assessment in the results section.

Table 4. Fixed and variable operating \& maintenance cost assumptions for the GSC plant.

\begin{tabular}{|c|c|c|}
\hline Fixed O\&M Costs & & \\
\hline Operating labour & \multicolumn{2}{|c|}{ Included in maintenance } \\
\hline Maintenance and administrative costs & $56[8]$ & $€ / \mathrm{kW} /$ year \\
\hline Cost of coal & $2.5[32]$ & $€ / G J$ LHV \\
\hline Cost of ash disposal & $9.73[32]$ & $€ / \mathrm{t}$ \\
\hline Cost of NG & $6.5[8]$ & $€ / G J ~ L H V$ \\
\hline \multicolumn{3}{|l|}{ Variable O\&M Costs } \\
\hline Process water costs & $6[8]$ & $€ / \mathrm{t}$ \\
\hline Cooling water make up costs & $0.325[8]$ & $€ / \mathrm{t}$ \\
\hline \multicolumn{3}{|l|}{ Catalyst Replacement } \\
\hline Oxygen carrier & $12,500[35]$ & $€ / \mathrm{t}$ \\
\hline Selexol ${ }^{\mathrm{TM}}$ replacement & $5000[8]$ & $€ / \mathrm{t}$ \\
\hline \multicolumn{3}{|l|}{$\mathrm{CO}_{2}$ Costs } \\
\hline Transport and storage & 10 [35] & $€ / \mathrm{t}$ \\
\hline \multicolumn{3}{|l|}{ Chemicals } \\
\hline Cooling water chemical treatment & $0.0025[35]$ & $€ / \mathrm{m}^{3}$ \\
\hline Process water chemical treatment & $45,000[35]$ & $€ / \mathrm{mo}$ \\
\hline
\end{tabular}


The oxygen carrier replacement period is selected as two years (also varied in a sensitivity analysis later), and the Selexol ${ }^{\mathrm{TM}}$ absorbent loss in the system is assumed to be $7 \mathrm{~g}$ lost/MWh gross power generated [8]. The economic parameters used for the OC in the GSOP reactors are the same as in the case of the GSC option.

\subsubsection{Cash Flow Analysis}

The levelized cost of electricity (LCOE) is calculated as the electricity price that would yield a net present value (NPV) of zero at the end of the plant's economic lifetime, according to Equation (10). Here, $i$ is the discount rate, and ACF is the annual cash flow in every year over the construction and operating periods specified in Table 5. The annual cash flow combines revenues from electricity sales and expenditures from capital, fuel, and O\&M costs. The construction period for the reference case without $\mathrm{CO}_{2}$ capture is assumed to be lower, 3 years. A sensitivity analysis to the discount rate and capacity factor is presented in the results section.

Table 5. Cash flow analysis assumptions.

\begin{tabular}{cc}
\hline Economic lifetime & 25 years \\
Discount rate & $8 \%$ \\
Construction period & 4 years \\
Capacity factor & $85 \%$ \\
First year capacity factor & $65 \%$ \\
\hline
\end{tabular}

The cost of $\mathrm{CO}_{2}$ avoidance (COCA) is calculated using Equation (11), where LCOE represents the levelized cost of electricity and $\mathrm{E}$ the specific $\mathrm{CO}_{2}$ emissions of the plant, respectively. Subscript $\mathrm{CC}$ denotes the plant with $\mathrm{CO}_{2}$ capture and ref the reference plant without $\mathrm{CO}_{2}$ capture, respectively:

$$
\begin{gathered}
\mathrm{NPV}=\sum_{\mathrm{t}=0}^{\mathrm{n}} \frac{\mathrm{ACF}_{\mathrm{t}}}{(1+\mathrm{i})^{\mathrm{t}}} \\
\operatorname{COCA}\left(\frac{€}{\mathrm{tCO}_{2}}\right)=\frac{\mathrm{LCOE}_{\mathrm{cc}}-\mathrm{LCOE}_{\mathrm{ref}}}{\mathrm{E}_{\mathrm{ref}}-\mathrm{E}_{\mathrm{cc}}}
\end{gathered}
$$

COCA is calculated based on two references: the IGCC plant evaluated in this study (COCA $\left.\mathrm{IGCC}_{\mathrm{I}}\right)$ and the supercritical pulverized coal plant from previous work [9] (COCASCPC). The supercritical pulverized coal plant has an LCOE of $€ 55.7 / \mathrm{MWh}$ and an emission intensity (E) of $763 \mathrm{~kg} / \mathrm{MWh}$.

\section{Results}

The results will be presented in four parts. First, a brief outline of the revised plant performance will be given. Second, the economic performance of the different plants under base-case assumptions will be presented. Third, a sensitivity analysis to the most uncertain assumptions will be presented. And finally, the economic performance of these plants will be compared to other clean energy supply technologies.

\subsection{Power Plant Performance Summary}

The model results shown in Table 6 reveal similar values to those presented in previous work $[17,21]$ for the plants using gas switching technology, while the reference IGCC plants with and without CCS show a comparable performance to Franco et al. [8]. A few small differences from these previous works can be highlighted:

- $\quad$ The lower heating value of coal was adjusted with an increase of $181 \mathrm{~kJ} / \mathrm{kg}(0.72 \%)$ to match Franco et al. [8], relative to the property estimation value from Unisim Design R451 used in our previous studies $[17,21]$. 
- The GSC-AF case shows around 0.5\%-points lower efficiency relative to our previous study [17] because the GT model was improved to consider cooling flows, with a pressure ratio of 18.1 compared to 20 in the previous assessment. A larger natural gas heat input is required due to the increased air flow rate across the expander, leading to a small decrease in the $\mathrm{CO}_{2}$ capture rate of $2 \%$-points and a net power output increase by $8 \%$.

- The $\mathrm{CO}_{2}$ compression for the plants integrating GSC technology consists of two intercooled stages and a supercritical $\mathrm{CO}_{2}$ pump instead of the $\mathrm{CO}_{2}$ purification unit used previously [17]. This simplification results from the improvement in $\mathrm{CO}_{2}$ purity enabled by the larger oxygen carrying capacity of $\mathrm{NiO}(8.6 \mathrm{wt} \%$ [36]) relative to the previously simulated ilmenite (3.3 $\mathrm{wt} \%$ [37]), which allows for an almost $3 \times$ longer time between valve switches. Such a reduced switching frequency reduces the amount of undesired $\mathrm{N}_{2} / \mathrm{CO}_{2}$ mixing taking place after the feed streams are switched [16], improving $\mathrm{CO}_{2}$ purity. Lower $\mathrm{N}_{2} / \mathrm{CO}_{2}$ mixing also facilitates a $1 \%$-point increase in capture rate. However, the longer cycles cause a slightly lower reactor temperature, reducing the efficiency by $0.1 \%$-points.

- The OPPC results given in Table 6 represent the case from our previous work [21] with the GSOP cluster operating at $900{ }^{\circ} \mathrm{C}$, employing Selexol ${ }^{\mathrm{TM}}$ for $\mathrm{CO}_{2}$ capture and no $\mathrm{H}_{2}$ fuel dilution (only saturation with water with low temperature residual heat). The $\mathrm{CO}_{2}$ capture ratio is 1\%-point lower than the value reported in [21], as a result of the lower partial pressure of $\mathrm{CO}_{2}$ in the syngas, which reduces the capture performance of the Selexol unit. The syngas is produced at lower pressure as the gasification pressure is fixed by the GT pressure ratio, which in this study is fixed to 18.1, relative to the value of 20 assumed in the earlier work.

Table 6. Power plant performance summary.

\begin{tabular}{cccccc}
\hline Item/Plant & IGCC & IGCC-PCC & GSC & GSC-AF & OPPC \\
\hline Gas Turbine Net (MW) & $283.3^{*}$ & 268.5 & 209.7 & 369.5 & 244.0 \\
Steam Turbine Net (MW) & 189.3 & 157.9 & 220.4 & 277.1 & 193.8 \\
Heat Input (MW) & 854.0 & 854.0 & 854.0 & 1176.8 & 854.0 \\
Total Auxiliaries (MW) & 66.0 & 104.1 & 62.1 & 63.8 & 42.4 \\
Gross Plant (MW) & 472.7 & 426.3 & 430.1 & 646.6 & 437.9 \\
Net Plant (MW) & 406.7 & 322.2 & 368.0 & 582.8 & 395.5 \\
Gross Efficiency (LHV \%) & 55.4 & 49.9 & 50.4 & 55.0 & 51.3 \\
Net Efficiency (LHV \%) & 47.6 & 37.7 & 43.1 & 49.5 & 46.3 \\
Specific Emissions & 727.3 & 86.4 & 46.6 & 135.1 & 123.3 \\
(kgCO /MWh) & 0.0 & 90.6 & 94.2 & 78.1 & 83.2 \\
Capture Rate (\%) & & & &
\end{tabular}

* includes air expander.

Table 6 shows that the IGCC-PCC benchmark plant suffers a large 9.9\%-point energy penalty relative to the unabated IGCC case, while the advanced process configurations greatly reduce this penalty. In the case of GSC-AF, the efficiency is even higher than the unabated IGCC plant due to the added firing with natural gas. However, this added natural gas firing causes $56 \%$ higher specific emissions than the IGCC-PCC benchmark, although emissions remain $5.4 \times$ lower than the IGCC plant. The OPPC model achieves only slightly lower specific emissions relative to the GSC-AF plant despite a 5\%-point higher capture rate, given that its thermal efficiency is $3 \%$-points lower and all combusted fuel is derived from carbon-intensive coal syngas. The GSC case is the only advanced plant that achieves lower specific emissions than the IGCC-PCC benchmark, although there is a tradeoff in terms of lower efficiency relative to the GSC-AF and OPPC configurations. 


\subsection{Base Case Economic Assessment}

Capital costs generally represent the largest component of the LCOE of coal-fired plants with CCS. Figure 6 presents the capital cost breakdown in the GSC case. The gasifier and gas switching reactor island are the most expensive components of the plant. The rest of the units' share is at $10 \%$ or lower. It is also noteworthy that the power cycle represents only a third of the capital costs of the plant. The units involved in the chemical transformation of coal and $\mathrm{CO}_{2}$ compression represent the other two thirds of the plant cost. This implies that any measures to get more useful electricity from the hot depleted air stream in the power cycle (such as the added firing with natural gas) can offer substantial reductions in the levelized capital cost of the plant.

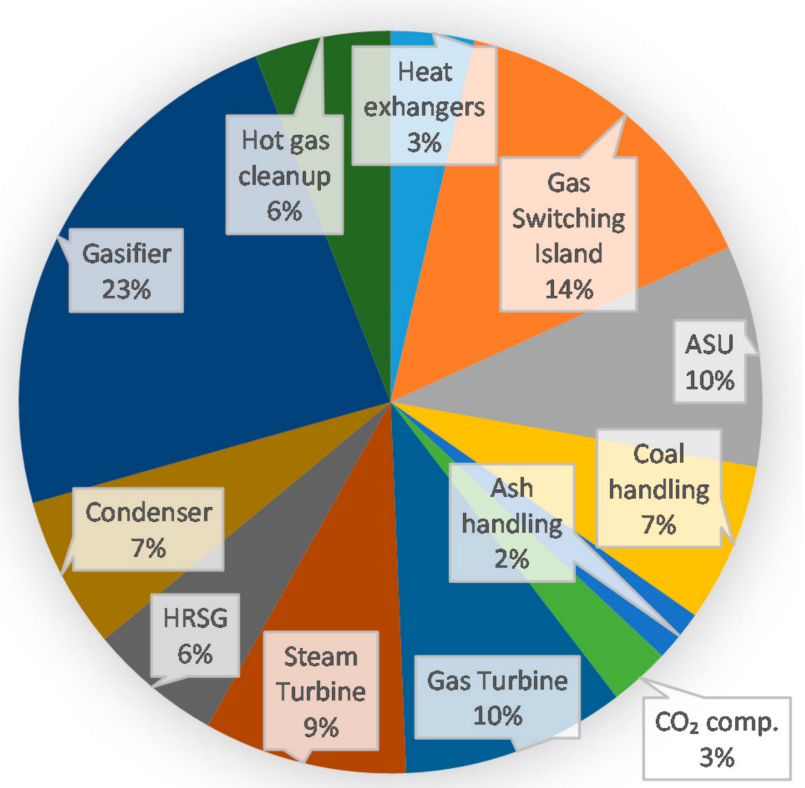

Figure 6. Total installed cost breakdown for the GSC case.

As presented in Table 7, the gasifier has the highest cost in all cases, with the gas turbine, gas switching island, and ASU also representing major shares of the plant capital cost. It is also interesting to note that the GSC plant relies more on the expensive steam cycle components (steam turbine, HRSG, and condenser) rather than the cheaper gas turbine relative to the other plants because of the relatively low TIT of this case. More power production from the gas turbine facilitated by the extra firing results in a more cost-effective power cycle. The OPPC plant suffers from a high gasifier cost due to the syngas flowrate that is more than double the size of the other plants. This high syngas flowrate also increases the gas clean-up cost.

The maintenance cost for the plant includes the labor cost, and it is calculated as a function of the gross power output of the plant, this explains the substantial difference between the two GSC models, the GSC-AF plant having a significantly higher output, as presented in Table 7. Variable O\&M costs depend on the capacity factor, and this could change from year to year and can be expected to drop by the end of the economic lifetime. Table 8 presents O\&M costs for the evaluated cases assuming a capacity factor of $85 \%$, as used in the economic model. For the GSC-AF case, the high cost of natural gas is clearly shown, given that it represents only about a quarter of the LHV fuel input to the plant. Besides fuel costs, the costs associated with $\mathrm{CO}_{2}$ storage have the highest impact on the economics of the plant. In the GSC plants, oxygen carrier replacement costs are also significant. These plants achieve a small process water revenue because of the water recovered from the high-pressure $\mathrm{CO}_{2}$-rich stream from the GSC reactors. 
Table 7. Installed costs for the main process components in each case.

\begin{tabular}{|c|c|c|c|c|c|}
\hline Unit & IGCC & IGCC-PCC & GSC & GSC-AF & OPPC \\
\hline Heat exchangers & & & 26.63 & 13.14 & 33.37 \\
\hline Gas Switching Island & & & 106.52 & 106.52 & 52.11 \\
\hline ASU & 70.07 & 70.60 & 70.60 & 70.60 & \\
\hline Coal handling & 52.03 & 50.79 & 50.79 & 50.79 & 50.79 \\
\hline Ash handling & 16.78 & 16.42 & 16.42 & 16.42 & 17.71 \\
\hline $\mathrm{CO}_{2}$ compression & & 34.86 & 19.32 & 19.56 & 31.56 \\
\hline Gas Turbine & 99.62 & 91.21 & 71.24 & 125.53 & 82.90 \\
\hline Steam Turbine & 58.73 & 51.86 & 64.84 & 75.61 & 59.58 \\
\hline HRSG & 37.87 & 34.01 & 42.52 & 49.58 & 39.07 \\
\hline Condenser & 43.31 & 38.89 & 48.63 & 56.71 & 44.68 \\
\hline Gasifier & 170.30 & 172.08 & 172.08 & 172.08 & 232.28 \\
\hline Hot gas clean-up & & & 43.26 & 43.28 & 72.15 \\
\hline WGS & & 19.47 & & & 20.18 \\
\hline Gas clean-up & 57.21 & 56.70 & & & \\
\hline Selexol ${ }^{\mathrm{TM}}$ plant & & 42.71 & & & 39.29 \\
\hline Total Install cost (M€) & 605.93 & 679.60 & 732.86 & 799.83 & 776.70 \\
\hline Total overnight cost (M€) & 912.91 & 1023.91 & 1104.15 & 1205.04 & 1170.20 \\
\hline Net power output (MW) & 406.69 & 322.19 & 367.95 & 582.80 & 395.48 \\
\hline Specific investment cost $(€ / \mathrm{kWe})$ & 2244.71 & 3178.00 & 3000.79 & 2067.68 & 2958.89 \\
\hline
\end{tabular}

Table 8. O\&M costs for the different cases.

\begin{tabular}{|c|c|c|c|c|c|}
\hline Fixed O\&M Costs (M€/Year) & IGCC & IGCC-PCC & GSC & GSC-AF & OPPC \\
\hline Maintenance incl. labour & 23.64 & 23.87 & 24.09 & 32.33 & 24.52 \\
\hline \multicolumn{6}{|c|}{ Variable O\&M costs at $85 \%$ capacity factor (M€/Year) } \\
\hline Cost of coal & 57.27 & 57.27 & 57.27 & 57.27 & 57.27 \\
\hline Cost of NG & & & & 56.28 & \\
\hline Cost of ash disposal & 1.25 & 1.25 & 1.25 & 1.25 & 1.40 \\
\hline Process water & 3.20 & 6.67 & -1.86 & -1.87 & 2.24 \\
\hline Cooling water consumption & 1.22 & 1.30 & 1.35 & 1.68 & 1.33 \\
\hline Oxygen carrier replacement & & & 3.82 & 3.82 & 2.09 \\
\hline WGS catalyst replacement & & 0.44 & & & 0.44 \\
\hline Selexol ${ }^{\mathrm{TM}}$ make up & 0.12 & 1.03 & & & 0.94 \\
\hline $\mathrm{CO}_{2}$ transport and storage & & 19.99 & 21.61 & 21.65 & 18.01 \\
\hline Total cost (M€/Year) & 86.71 & 111.82 & 107.53 & 172.41 & 108.24 \\
\hline
\end{tabular}

The main economic performance indicators are presented in Table 9 for all cases. The conventional pre-combustion capture plant has the highest LCOE, followed by the GSC and OPPC plants that reduce LCOE by 10 and $13 € / \mathrm{MWh}$, respectively. Added natural gas firing reduces the LCOE by an additional $13 € /$ MWh relative to the standard GSC plant. As discussed earlier, the gasifier cost is an important uncertainty in the estimation of the OPPC cost. For perspective, the LCOE of this case reduces to $76.37 € / M W h$ if the gasifier costs are scaled only by the thermal input and increases to $83.00 € / \mathrm{MWh}$ if scaled only by the raw syngas flowrate. Trends in the COCA indicators are similar to those in the LCOE, although the COCA of the GSC-AF and OPPC plants are increased by their higher $\mathrm{CO}_{2}$ emissions intensities (Table 6). 
Table 9. LCOE and COCA indicators for each case.

\begin{tabular}{cccccc}
\hline & IGCC & IGCC-PCC & GSC & GSC-AF & OPPC \\
\hline LCOE $[€ / M W h]$ & 61.23 & 92.74 & 82.79 & 69.75 & 79.68 \\
COCA $_{\text {IGCC }}[€ /$ ton] & - & 49.16 & 31.67 & 14.39 & 30.55 \\
COCA $_{\text {SCPC }}[€ /$ ton] & - & 54.74 & 37.82 & 22.38 & 37.50 \\
\hline
\end{tabular}

Figure 7 shows the breakdown of the LCOE for all cases considered in this paper. Fuel cost and O\&M costs have similar ratios in the cost breakdown of the LCOE for the four carbon capture cases, capital cost being the one that varies from technology to technology. In the IGCC-AF case, the capital cost reduction obtained is counteracted to some extent by the higher cost of the NG. Even so, the overall cost is substantially reduced relative to the base GSC case and the OPPC case.

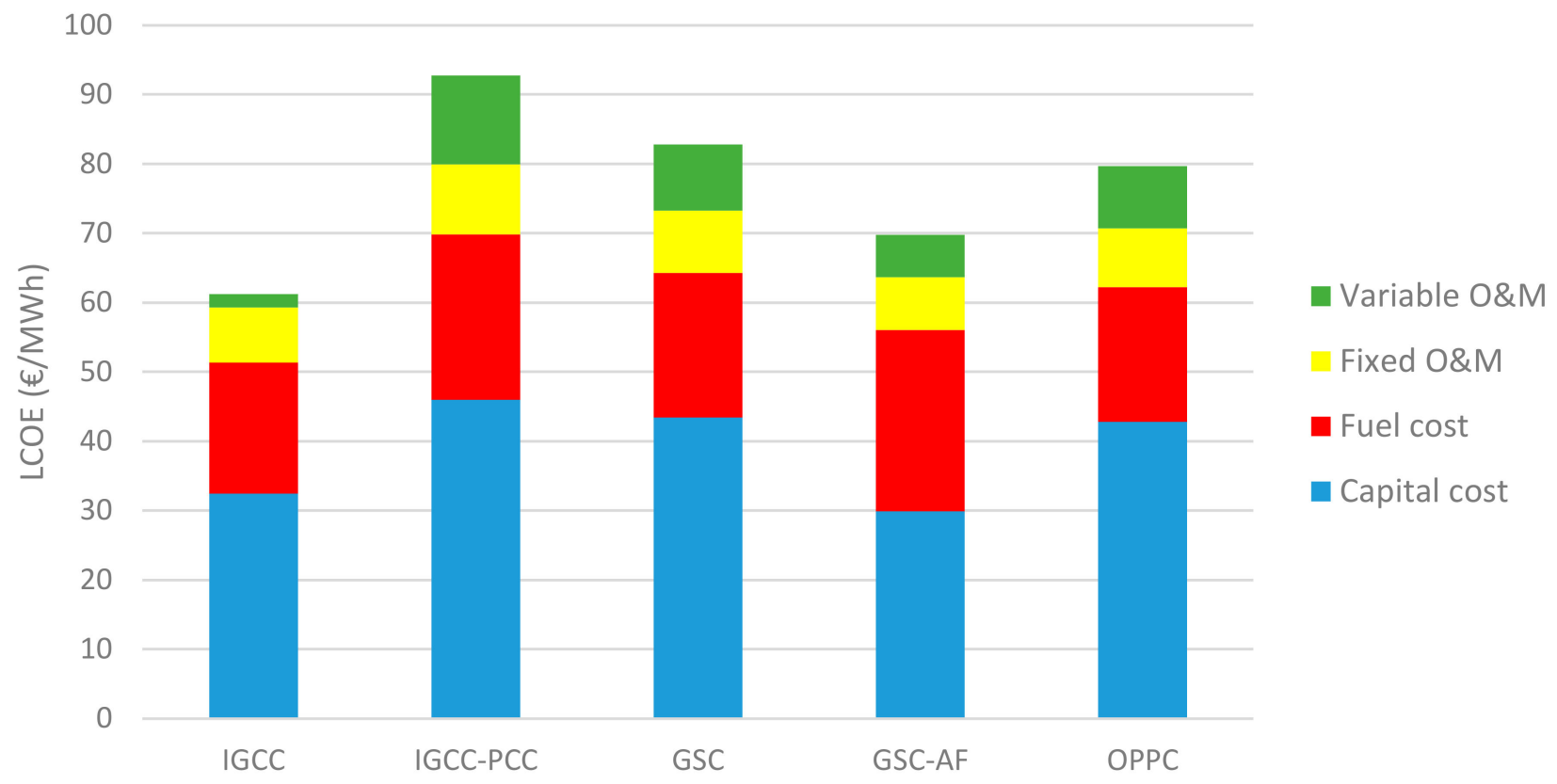

Figure 7. LCOE breakdown for the five IGCC configurations.

\subsection{Sensitivity Analysis}

The LCOE is sensitive to the cost of the fuel, as presented in Figure 8a,b, respectively. In all cases, aside from the GSC-AF case, the slopes of the lines in Figure 8a are inversely proportional to the plant efficiency. The GSC-AF plant has the lowest degree of dependency on the cost of coal because, in addition to having the highest efficiency, about a quarter of its fuel input is NG.

When the natural gas price is varied, a high degree of dependency is observed in the GSC-AF case, because of the high cost of natural gas when compared to coal. It is noteworthy that the LCOE of the GSC-AF plant remains lower than the GSC plant even at a natural gas cost of $€ 10 / G J(4 \times$ higher than the coal cost). This illustrates the large benefit of using natural gas to raise the TIT so that the syngas produced by the costly gasification train can be converted to electricity more efficiently. 

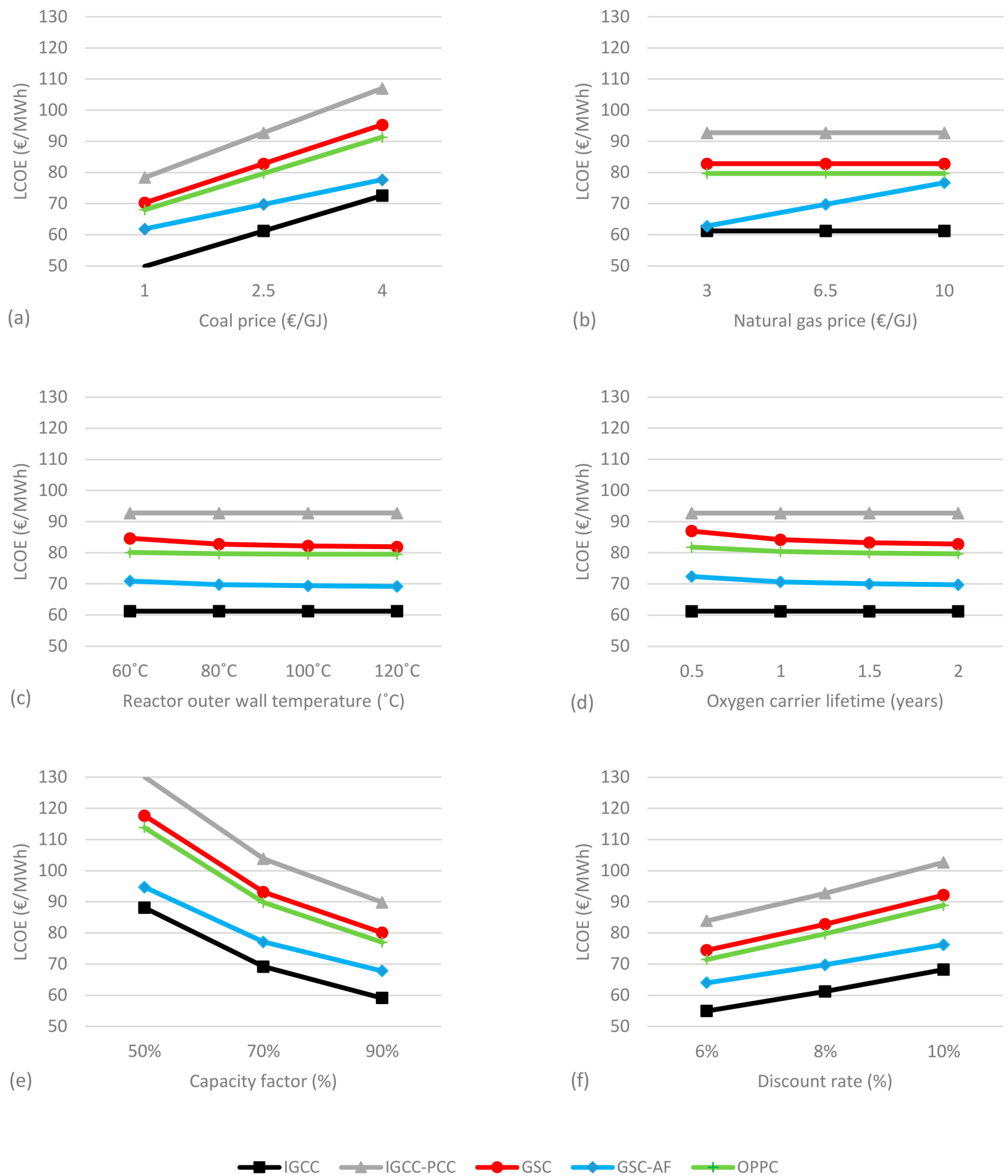

Figure 8. Sensitivity analysis to coal (a) and natural gas (b) prices, reactor outer wall temperature (c), oxygen carrier lifetime (d), capacity factor $(\mathbf{e})$, and discount rate (f).

The outer carbon steel shell, carrying the pressure load in the GSC reactors, is the component showing the highest sensitivity because an increase in the insulation layer thickness increases both the shell volume and its required thickness, thus strongly increasing its cost. Increasing the insulation thickness from $0.54 \mathrm{~m}$ to $0.88 \mathrm{~m}$ in the GSC case lowers the shell temperature by $20^{\circ} \mathrm{C}$, but increases the LCOE by $1.86 € / \mathrm{MWh}$ (Figure $8 \mathrm{c}$ ). Allowing the shell temperature to reach $100{ }^{\circ} \mathrm{C}$ reduces the insulation thickness to $0.38 \mathrm{~m}$ while the LCOE drops with $0.6 € / \mathrm{MWh}$. Thus, even though the total reactor cost increased by $43 \%$ 
from the $100{ }^{\circ} \mathrm{C}$ wall temperature to the $60{ }^{\circ} \mathrm{C}$ wall temperature, the effect on the LCOE is relatively small. The effect is even smaller in the GSC-AF and OPPC cases where the gas switching reactors represent a smaller fraction of total plant costs. The calculated heat losses for the three temperatures on the total surface of the reactors in the case of the GSC plant are $893.8 \mathrm{~kW}, 1113.5 \mathrm{~kW}$, and $1365.9 \mathrm{~kW}$, representing a bit more than $0.1 \%$ of the heat input.

Oxygen carrier lifetime is another important uncertainty for all concepts based on chemical looping technology. For the base case, a two-year replacement period is assumed for both GSC and GSOP reactors. As presented in Figure 8d, the LCOE would increase in all cases if the OC lifetime reduces. The GSC case is the most sensitive to the OC lifetime, showing a $4.2 € / \mathrm{MWh}$ increase in LCOE if the OC lifetime reduces from 2 years to 0.5 years.

Given the capital-intensive nature of these plants, capacity factor and discount rate have the highest effect on the LCOE. A reduced capacity factor strongly increases the LCOE, as presented in Figure 8e. With the rapid growth of wind and solar power, thermal power plants are increasingly expected to act as balancing capacity, operating at lower capacity factors. In this respect, the GSC-AF plant offers some additional benefits because it is the least capital intensive, and, under part-load operation, it will reduce the fraction of fuel input required from more expensive natural gas. For example, when the F-class gas turbine output reduces by a little more than 50\%, the TIT falls to the GSC outlet temperature [38], thus requiring no more natural gas firing. Under these conditions, the plant can operate with only a mild turndown of the relatively inflexible gasification train, but a substantial turndown in overall plant output, saving the high natural gas fuel costs and associated $\mathrm{CO}_{2}$ emissions. The variation of the discount rate also has a large effect on the LCOE for all cases (Figure 8f), with the GSC-AF case being the least sensitive due to its relatively low specific capital cost.

\subsection{Benchmarking against Other Clean Energy Technologies}

In today's energy market, the COCA relative to unabated fossil fuel plants is not the most important indicator of the competitiveness of CCS technologies. Alternative clean energy technologies represent a more relevant benchmark. For this reason, the power plants assessed in this paper will be benchmarked against nuclear, wind, and solar technologies with cost data outlined in Table 10. Technology costs are taken from the IEA World Energy Outlook [39] for the year 2040 in the European Union. Wind and solar power integration costs, resulting from their large temporal and spatial variability, are taken from Hirth et al. [40] and are appropriate to the European Union for a wind and solar market share of 30-40\%, increasing further for higher shares. Although nuclear and CCS plants would generally have longer operating lifetimes, all plants are assumed to have a 25-year economic lifetime. This assumption will give a conservative estimate of the competitiveness of the CCS plants evaluated in this study.

Table 10. Cost assumptions for nuclear, wind and solar benchmarks.

\begin{tabular}{cccc}
\hline & Nuclear & Onshore Wind & Solar PV \\
\hline Capital cost $(€ / \mathrm{kW})$ & 3750 & 1417 & 508 \\
Construction period (years) & 6 & 1 & 1 \\
Capacity factor & $85 \%$ & $30 \%$ & $14 \%$ \\
O\&M costs $(€ / \mathrm{MWh})$ & 20 & 15 & 10 \\
Fuel costs $(€ / \mathrm{MWh})$ & 15 & & $25-35$ \\
Integration costs $(€ / \mathrm{MWh})$ & & $25-35$ & 25 \\
\hline
\end{tabular}

Figure 9 shows the results of this benchmarking exercise. Clearly, the conventional $\mathrm{CO}_{2}$ capture plant (IGCC-PCC) is not well positioned in the competitive clean energy landscape. It is significantly more expensive than nuclear, only on par with wind and considerably more expensive than solar. Given the negligible air pollution and general green appeal of wind and solar energy, these clean technologies will be preferred over CCS 
if costs are similar. The GSC and OPPC plants achieve a better competitive position, being significantly cheaper than wind and nuclear and on par with solar with the higher integration costs bound. Only the GSC-AF plant outperforms other clean energy benchmarks, although only slightly in the case of solar. However, solar in Europe is subject to substantial seasonal variations that are misaligned with the seasonal electricity demand profile. Thus, Europe will continue relying strongly on wind despite the lower future LCOE projected for solar. It is noteworthy that the capital cost portion of the LCOE of the GSC-AF plant is lower even than that of solar PV, which has a $4 \times$ lower investment cost. This results from the $6 x$ lower capacity factor of solar PV.

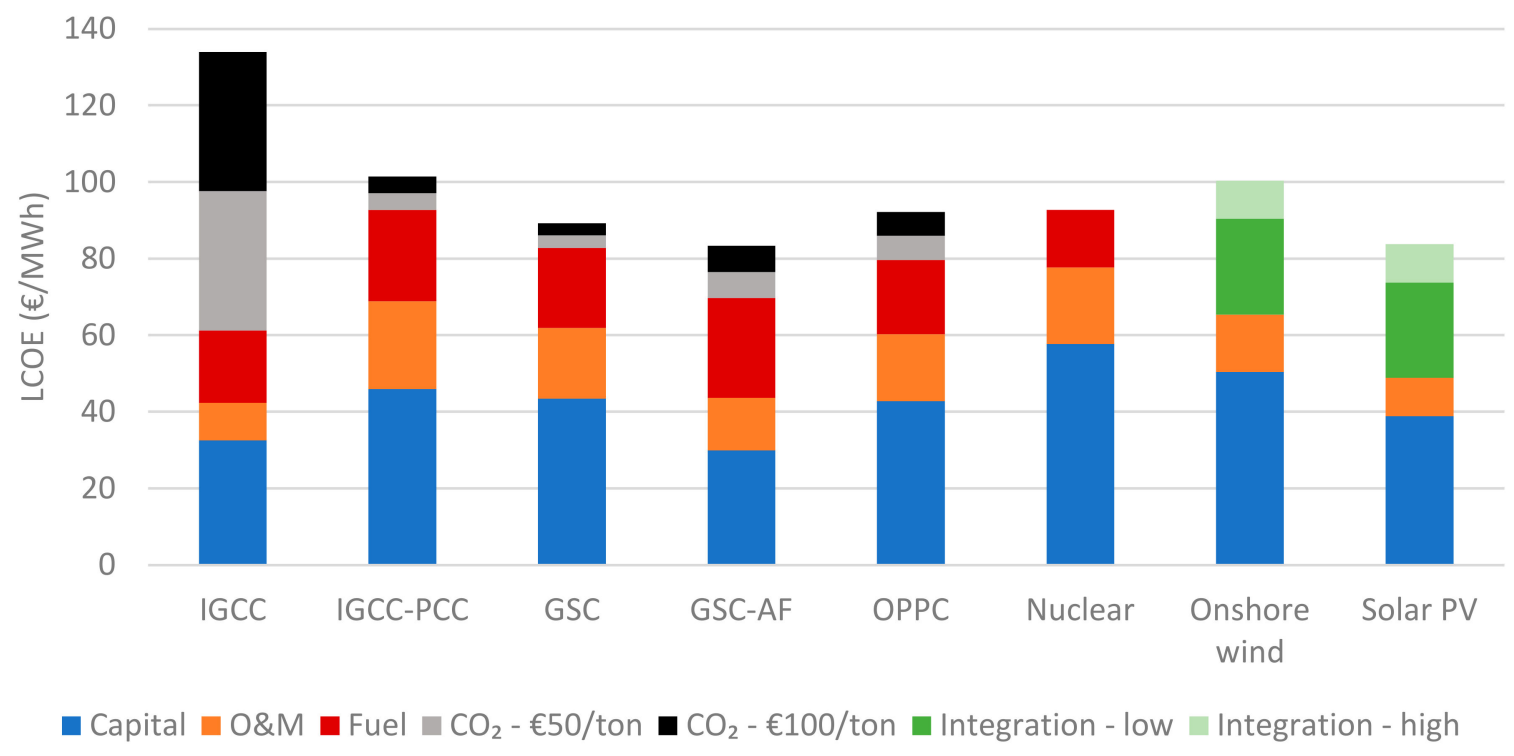

Figure 9. Benchmarking of the five IGCC-based power plants evaluated in this study against nuclear, wind, and solar power using costs relevant to the year 2040 when the $\mathrm{CO}_{2}$ price is set to $50-100 €$ /ton.

Figure 9 also shows that the significant $\mathrm{CO}_{2}$ emissions resulting from the combustion of natural gas after the GSC reactors in the GSC-AF plant reduces its competitiveness if $\mathrm{CO}_{2}$ prices become very high. When the $\mathrm{CO}_{2}$ price approaches $€ 100 /$ ton, it will become economical to do the added firing with clean hydrogen instead as recently calculated for a CLC-NGCC plant [41]. This possibility means $\mathrm{CO}_{2}$ prices higher than $€ 100 /$ ton will not further increase the LCOE of the GSC-AF plant. Furthermore, a moderate fraction of biomass co-firing has the potential to bring $\mathrm{CO}_{2}$ emissions below zero to achieve ultra-low emission targets while avoiding most of the technical challenges associated with biomass gasification and combustion.

This result suggests that highly efficient plants like the GSC-AF configuration will be required for CCS to be competitive in the clean energy landscape of the future. It should be noted, however, that the GSC-AF and OPPC configurations can benefit from using more advanced gas turbines with higher TITs to further increase efficiency and reduce costs. Flexibility is also an important criterion for the attractiveness of new CCS plants as the expansion of variable renewables continues [42]. The higher degree of flexibility offered by the GSC-AF case further increases its competitive position relative to the other CCS plants evaluated in this study.

\section{Summary and Conclusions}

This study compared the economic performance of five different IGCC power plant configurations: a benchmark IGCC plant without CCS, conventional pre-combustion CCS, gas switching combustion (GSC), GSC with added firing with natural gas (GSC-AF) to increase the TIT, and the oxygen production pre-combustion (OPPC) configuration that 
replaces the air separation unit (ASU) with more efficient gas switching oxygen production (GSOP) reactors.

The GSC plant returned a 10.7\% lower LCOE than the conventional pre-combustion benchmark (82.7 $€ / \mathrm{MWh}$ vs. $92.7 € / \mathrm{MWh}$ ) while maintaining a $\mathrm{CO}_{2}$ capture rate of over $94 \%$. Despite the higher cost of natural gas relative to coal, the high efficiency of the GSC-AF plant reduced the LCOE by another $15.7 \%$ to $69.8 € / \mathrm{MWh}$, reducing the cost of $\mathrm{CO}_{2}$ avoidance as low as $22.4 € /$ ton when compared to a supercritical pulverized coal power plant. The large efficiency benefit of replacing the ASU with GSOP reactors in the OPPC configuration was partially counteracted by an increase in the gasifier cost and a lower $\mathrm{CO}_{2}$ capture rate, resulting in a similar $\mathrm{CO}_{2}$ avoidance cost to the GSC plant, despite achieving a $3.8 \%$ lower LCOE.

These results reveal that the GSC-AF configuration holds the most promise. In the sensitivity analysis, this case also showed reduced risk from several sources of uncertainty. Fuel costs are split evenly between coal and natural gas, limiting the sensitivity to price variations in either fuel. Uncertainties related to the GSC reactor cost and oxygen carrier lifetime are also limited since the added firing makes these components a smaller fraction of the LCOE. Added natural gas firing also makes the GSC-AF case less capital intensive (30\% lower specific capital cost than GSC), limiting the cost increase related to lower capacity factors and higher discount rates. This plant could also hold benefits related to flexible operation for balancing wind and solar power since the expensive natural gas consumption can be ramped down first during part-load operation, requiring only a modest turndown of the relatively inflexible gasification train. The GSC-AF plant faces some risk from very high $\mathrm{CO}_{2}$ prices due to the emissions from added natural gas firing, but this risk is mitigated by the possibility to do the added firing with clean hydrogen instead.

The good performance of the GSC-AF case was confirmed in comparisons to nuclear, wind, and solar power, where it emerged as the only CCS technology consistently less expensive than other clean energy benchmarks. Among the advanced IGCC power plant configurations investigated in this study, the GSC-AF configuration therefore emerges as the preferred option for further development. Future work will investigate the possibility of further performance gains using more advanced gas turbine technology and the potential to do the added firing with hydrogen extracted from the syngas stream.

Author Contributions: Conceptualization S.C.; methodology S.S., C.A.d.P. and S.C.; formal analysis, S.S., C.A.d.P., S.C. and S.F.; investigation, S.S. and C.A.d.P.; writing-original draft preparation, S.S., C.A.d.P. and S.C.; writing-review and editing, Á.J.Á., A.-M.C., C.-C.C., and S.A.; supervision, S.C., Á.J.Á. A.-M.C., and C.-C.C.; project administration, S.A.; funding acquisition, S.C, Á.J.Á., A.-M.C. and S.A. All authors have read and agreed to the published version of the manuscript.

Funding: This research was funded by the European Commission Horizon 2020 program, the Romanian National Authority for Scientific Research and Innovation, the Ministerio de Economía y Competitividad, and the Research Council of Norway under the ACT Grant Agreement No 691712.

Institutional Review Board Statement: Not applicable.

Informed Consent Statement: Not applicable.

Data Availability Statement: Data can be provided by the first author (szabolcs.szima@gmail.com) upon reasonable request.

Acknowledgments: The authors would also like to acknowledge Honeywell for the free academic license of Unisim Design R451 for the modelling of the power plants.

Conflicts of Interest: The author Szabolcs Szima is an employee of MDPI, however he does not work for the journal Clean Technologies at the time of submission and publication. 


\section{List of Abbreviations}

ASU Air separation unit

CCS $\quad \mathrm{CO}_{2}$ capture and storage

CLC Chemical looping combustion

COCA Cost of $\mathrm{CO}_{2}$ avoidance

COT Combustor inlet temperature

EPCC Engineering, procurement and construction cost

GS Gas Switching

GSC Gas switching combustion

GSC-AF GSC power plant with added natural gas firing

GSOP Gas switching oxygen production

GT Gas Turbine

HGCU Hot gas clean up

HRSG Heat recovery steam generator

IGCC Integrated gasification combined cycle

LCOE Levelized cost of electricity

NPV Net present value

O\&M Operating and maintenance

OPPC Oxygen production pre-combustion power plant

PS Process contingency

PT Project contingency

TIC Total install cost

TIT Turbine inlet temperature

TPC Total plant cost

WGS Water-gas shift

\section{Appendix A}

Table A1. Gasification island assumptions.

\begin{tabular}{|c|c|c|}
\hline \multicolumn{3}{|c|}{ Winkler Gasifier } \\
\hline Item & Value & Units \\
\hline Freeboard Temperature & 900 & ${ }^{\circ} \mathrm{C}$ \\
\hline$\%$ w. $\mathrm{CO}_{2}$ for coal loading & 15 & $\%$ \\
\hline$\% \mathrm{LHV} \mathrm{CH}_{4}$ in syngas & 11.3 & $\%$ \\
\hline Oxidizer Overpressure & 50 & $\mathrm{kPa}$ \\
\hline HP steam superheat & 450 & ${ }^{\circ} \mathrm{C}$ \\
\hline Fixed carbon conversion & 97 & $\%$ \\
\hline$\%$ w. Vented $\mathrm{CO}_{2}$ in lock hoppers & 10 & $\%$ \\
\hline Coal milling \& handling & 40 & $\mathrm{MJ} / \mathrm{kg}$ coal \\
\hline Ash handling & 200 & $\mathrm{MJ} / \mathrm{kg}$ ash \\
\hline \multicolumn{3}{|c|}{ Shell Gasifier } \\
\hline Item & Value & Units \\
\hline Moderator (steam) to dry coal ratio & 0.09 & $\mathrm{~kg} / \mathrm{kg}$ \\
\hline Oxygen to dry coal ratio & 0.873 & $\mathrm{~kg} / \mathrm{kg}$ \\
\hline Moisture in Coal after drying & 2 & $\%$ \\
\hline Syngas for coal drying \%LHV & 0.9 & $\%$ \\
\hline Fixed carbon conversion & 99.3 & $\%$ \\
\hline Gasifier operating pressure & 44 & bar \\
\hline Steam moderator pressure & 54 & bar \\
\hline Heat loss as \%LHV & 0.7 & $\%$ \\
\hline Heat to membrane wall as \%LHV & 2 & $\%$ \\
\hline $\mathrm{CO}_{2} \mathrm{HP} / \mathrm{HHP}$ Pressure & $56 / 88$ & bar \\
\hline $\mathrm{CO}_{2}$ Temperature & 80 & ${ }^{\circ} \mathrm{C}$ \\
\hline $\mathrm{CO}_{2}$ to dry coal ratio & 0.83 & $\mathrm{~kg} / \mathrm{kg}$ \\
\hline
\end{tabular}


Table A1. Cont.

\begin{tabular}{ccc}
\hline \multicolumn{1}{c}{ Winkler Gasifier } & \\
\hline Air Separation Unit & & \\
\hline Item & Value & Units \\
Main air compressor polytropic efficiency & 89 & $\%$ \\
Booster air compressor polytropic efficiency & 87 & $\%$ \\
Reboiler-condenser pinch & 1.5 & ${ }^{\circ} \mathrm{C}$ \\
Heat exchanger minimum approach temperature & 2 & ${ }^{\circ} \mathrm{C}$ \\
Process stream temperature after heat rejection & 25 & ${ }^{\circ} \mathrm{C}$ \\
Oxygen purity & 95 & $\%$ \\
Oxygen delivery pressure & 48 & $\mathrm{bar}$ \\
Oxygen pump efficiency & 80 & $\%$ \\
Exchanger pressure losses/side & 10 & $\mathrm{kPa}$ \\
Intercooler pressure loss & 10 & $\mathrm{kPa}$ \\
\hline
\end{tabular}

Table A2. Syngas treating unit assumptions.

\begin{tabular}{ccc}
\hline & HGCU & \\
\hline Item & Value & Units \\
Adsorption temperature & 400 & ${ }^{\circ} \mathrm{C}$ \\
Regeneration temperature & 750 & ${ }^{\circ} \mathrm{C}$ \\
Filter pressure drop & 5 & $\%$ \\
Auxiliary consumption & 5.34 & $\mathrm{MJe} / \mathrm{kgH}_{2} \mathrm{~S}$ \\
Compander polytropic efficiency & 90 & $\%$ \\
Syngas blower polytropic efficiency & 80 & $\%$ \\
$\mathrm{O}_{2}$ mol fraction in regeneration stream & 2 & $\%$ \\
\hline \multicolumn{2}{c}{ CGCU } & \multicolumn{2}{c}{} \\
\hline Absorption temperature & Value & Units \\
Auxiliary consumption & 30 & ${ }^{\circ} \mathrm{C}$ \\
LP steam requirement & 3 & $\mathrm{MJe} / \mathrm{kg} \mathrm{H} \mathrm{H}_{2} \mathrm{~S}$ \\
Syngas blower polytropic efficiency & 50 & $\mathrm{MJth} / \mathrm{kg} \mathrm{H} \mathrm{H}_{2} \mathrm{~S}$ \\
Selexol pump efficiency & 80 & $\%$ \\
\% H $\mathrm{H}_{2} \mathrm{~S}$ to Claus unit & 80 & $\%$ \\
\hline
\end{tabular}

Table A3. Power cycle assumptions.

\begin{tabular}{ccc}
\hline & Gas Turbine & \\
\hline Item & Value & Units \\
GT compressor polytropic & 91.5 & $\%$ \\
efficiency & & $\%$ \\
GT turbine polytropic & 87 & - \\
efficiency & 18.1 & $\%$ \\
GT pressure ratio & 98.6 & \\
GT Electromechanical & & $\%$ \\
efficiency &
\end{tabular}


Table A3. Power cycle assumptions.

\begin{tabular}{|c|c|c|}
\hline \multicolumn{3}{|c|}{ Gas Turbine } \\
\hline \multicolumn{3}{|c|}{ Steam Cycle } \\
\hline Item & Value & Units \\
\hline $\begin{array}{l}\text { Steam turbine low pressure } \\
\text { stage isentropic efficiency }\end{array}$ & 88 & $\%$ \\
\hline $\begin{array}{l}\text { Steam turbine intermediate } \\
\text { pressure stage isentropic } \\
\text { efficiency }\end{array}$ & 94 & $\%$ \\
\hline $\begin{array}{l}\text { Steam turbine high pressure } \\
\text { stage isentropic efficiency }\end{array}$ & 92 & $\%$ \\
\hline $\begin{array}{l}\text { Steam turbine } \\
\text { electromechanical efficiency }\end{array}$ & 98.1 & $\%$ \\
\hline Pressure levels HP/IP/LP & $144 / 36 / 4$ & bar \\
\hline Auxiliaries for heat rejection & 0.008 & MJe/MJth \\
\hline Pump isentropic efficiency & 80 & $\%$ \\
\hline Live steam temperature & 565 & ${ }^{\circ} \mathrm{C}$ \\
\hline \multicolumn{3}{|c|}{$\mathrm{CO}_{2}$ Compression } \\
\hline Item & Value & Units \\
\hline $\begin{array}{l}\mathrm{CO}_{2} \text { Compressor stage } \\
\text { isentropic efficiency }\end{array}$ & 80 & $\%$ \\
\hline $\begin{array}{c}\text { Process stream temperature } \\
\text { after cooler }\end{array}$ & 25 & ${ }^{\circ} \mathrm{C}$ \\
\hline
\end{tabular}

\section{References}

1. IEA. World Energy Outlook. International Energy Agency, 2018. Available online: https://www.iea.org/reports/world-energy -outlook-2018 (accessed on 7 October 2019).

2. The Paris Agreement, n.d. Available online: https://unfccc.int/process-and-meetings/the-paris-agreement/the-paris-agreement (accessed on 7 October 2019).

3. AR5 Synthesis Report: Climate Change. 2014. Available online: https://www.ipcc.ch/report/ar5/syr/ (accessed on 7 October 2019).

4. Tracking Clean Energy Progress. 2020. Available online: https://www.iea.org/topics/tracking-clean-energy-progress (accessed on 1 October 2020).

5. Ishida, M.; Zheng, D.; Akehata, T. Evaluation of a chemical-looping-combustion power-generation system by graphic exergy analysis. Energy 1987, 12, 147-154. [CrossRef]

6. Lyngfelt, A.; Leckner, B.; Mattisson, T. A fluidized-bed combustion process with inherent $\mathrm{CO}_{2}$ separation; Application of chemical-looping combustion. Chem. Eng. Sci. 2001, 56, 3101-3113. [CrossRef]

7. Adánez, J.; Abad, A.; Mendiara, T.; Gayán, P.; de Diego, L.F.; García-Labiano, F. Chemical looping combustion of solid fuels. Prog. Energy Combust. Sci. 2018, 65, 6-66. [CrossRef]

8. Anantharaman, R.; Bolland, O.; Booth, N.; van Dorst, E.; Sanchez Fernandez, E.; Franco, F.; Macchi, E.; Manzolini, G.; Nikolic, D.; Pfeffer, A.; et al. Cesar Deliverable D2.4.3. European Best Practice Guidelines for Assessment of $\mathrm{CO}_{2}$ Capture Technologies; Technical Report Number: CESAR-D2.4.3; Zenodo Array: Geneve, Switzerland, 2011. [CrossRef]

9. Cloete, S.; Tobiesen, A.; Morud, J.; Romano, M.; Chiesa, P.; Giuffrida, A.; Larring, Y. Economic assessment of chemical looping oxygen production and chemical looping combustion in integrated gasification combined cycles. Int. J. Greenh. Gas Control 2018, 78, 354-363. [CrossRef]

10. Spallina, V.; Romano, M.C.; Chiesa, P.; Gallucci, F.; van Sint Annaland, M.; Lozza, G. Integration of coal gasification and packed bed CLC for high efficiency and near-zero emission power generation. Int. J. Greenh. Gas Control 2014, 27, 28-41. [CrossRef]

11. Hamers, H.P.; Romano, M.C.; Spallina, V.; Chiesa, P.; Gallucci, F.; van Annaland, M.S. Comparison on process efficiency for CLC of syngas operated in packed bed and fluidized bed reactors. Int. J. Greenh. Gas Control 2014, 28, 65-78. [CrossRef]

12. Cloete, S.; Giuffrida, A.; Romano, M.; Chiesa, P.; Pishahang, M.; Larring, Y. Integration of chemical looping oxygen production and chemical looping combustion in integrated gasification combined cycles. Fuel 2018, 220, 725-743. [CrossRef]

13. Sorgenfrei, M.; Tsatsaronis, G. Design and evaluation of an IGCC power plant using iron-based syngas chemical-looping (SCL) combustion. Appl. Energy 2014, 113, 1958-1964. [CrossRef]

14. Wu, W.; Wen, F.; Chen, J.R.; Kuo, P.C.; Shi, B. Comparisons of a class of IGCC polygeneration/power plants using calcium/chemical looping combinations. J. Taiwan Inst. Chem. Eng. 2019, 96, 193-204. [CrossRef] 
15. Zaabout, A.; Cloete, S.; Johansen, S.T.; van Sint Annaland, M.; Gallucci, F.; Amini, S. Experimental Demonstration of a Novel Gas Switching Combustion Reactor for Power Production with Integrated $\mathrm{CO}_{2}$ Capture. Ind. Eng. Chem. Res. 2013, 52, 14241-14250. [CrossRef]

16. Cloete, S.; Romano, M.C.; Chiesa, P.; Lozza, G.; Amini, S. Integration of a Gas Switching Combustion (GSC) system in integrated gasification combined cycles. Int. J. Greenh. Gas Control 2015, 42, 340-356. [CrossRef]

17. Arnaiz del Pozo, C.; Cloete, S.; Cloete, J.H.; Jiménez Álvaro, Á.; Amini, S. The potential of chemical looping combustion using the gas switching concept to eliminate the energy penalty of $\mathrm{CO}_{2}$ capture. Int. J. Greenh. Gas Control 2019, 83, 265-281. [CrossRef]

18. Moghtaderi, B. Application of chemical looping concept for air separation at high temperatures. Energy Fuels 2010, 24, 190-198. [CrossRef]

19. Shi, B.; Wu, E.; Wu, W. Novel design of chemical looping air separation process for generating electricity and oxygen. Energy 2017, 134, 449-457. [CrossRef]

20. Deng, Z.; Jin, B.; Zhao, Y.; Gao, H.; Huang, Y.; Luo, X.; Liang, Z. Process simulation and thermodynamic evaluation for chemical looping air separation using fluidized bed reactors. Energy Convers. Manag. 2018, 160, 289-301. [CrossRef]

21. Arnaiz del Pozo, C.; Cloete, S.; Hendrik Cloete, J.; Jiménez Álvaro, Á.; Amini, S. The oxygen production pre-combustion (OPPC) IGCC plant for efficient power production with $\mathrm{CO}_{2}$ capture. Energy Convers. Manag. 2019, 201. [CrossRef]

22. Gazzani, M.; MacChi, E.; Manzolini, G. $\mathrm{CO}_{2}$ capture in integrated gasification combined cycle with SEWGS-Part A: Thermodynamic performances. Fuel 2013, 105, 206-219. [CrossRef]

23. Kapetaki, Z.; Brandani, P.; Brandani, S.; Ahn, H. Process simulation of a dual-stage Selexol process for $95 \%$ carbon capture efficiency at an integrated gasification combined cycle power plant. Int. J. Greenh. Gas Control 2015, 39, 17-26. [CrossRef]

24. Kuusik, R.; Trikkel, A.; Lyngfelt, A.; Mattisson, T. High temperature behavior of NiO-based oxygen carriers for Chemical Looping Combustion. Energy Procedia 2009, 1, 3885-3892. [CrossRef]

25. Horlock, J.H. Cycle Efficiency with Turbine Cooling (Cooling Flow Rates Specified). Adv. Gas. Turbine Cycles Pergamon 2003, 47-69. [CrossRef]

26. Khan, M.N.; Cloete, S.; Amini, S. Efficiency Improvement of Chemical Looping Combustion Combined Cycle Power Plants. Energy Technol. 2019, 7, 1900567. [CrossRef]

27. Turton, R.; Bailie, R.C.; Whiting, W.B.; Shaeiwitz, J.A. Analysis, Synthesis, and Design of Chemical Processes, 3rd ed.; Pearson Education: Boston, MA, USA, 2008.

28. Bi, H.T.; Grace, J.R. Flow regime diagrams for gas-solid fluidization and upward transport. Int. J. Multiph. Flow 1995, 21, 1229-1236. [CrossRef]

29. Plant Cost Index Archives-Chemical Engineering. Available online: http:/ / www.chemengonline.com/ (accessed on 2 November 2017).

30. Bergman, T.L.; Lavine, A.S.; Incropera, F.S.; DeWitt, D.P. Fundamentals of Heat and Mass Transfer, 8th ed.; Wiley: Danvers, MA, USA, 2017.

31. Giuffrida, A.; Romano, M.C.; Lozza, G. Efficiency enhancement in IGCC power plants with air-blown gasification and hot gas clean-up. Energy 2013, 53, 221-229. [CrossRef]

32. Nexant. Preliminary Feasibility Analysis of RTI Warm Gas Clean Up (WGCU) Technology. 2007. Available online: https: / / fdocuments.in/document/preliminary-feasibility-analysis-of-rti-warm-gas-cleanup-wgcu-.html (accessed on 8 August 2021).

33. Spallina, V.; Pandolfo, D.; Battistella, A.; Romano, M.C.; Van Sint Annaland, M.; Gallucci, F. Techno-economic assessment of membrane assisted fluidized bed reactors for pure $\mathrm{H}_{2}$ production with $\mathrm{CO}_{2}$ capture. Energy Convers. Manag. 2016, 120, 257-273. [CrossRef]

34. Rubin, E.; Booras, G.; Davison, J.; Ekstrom, C.; Matuszewski, M.; Mccoy, S.; Short, C. Toward a Common Method of Cost Estimation for $\mathrm{CO}_{2}$ Capture and Storage at Fossil Fuel Power Plants A White Paper Prepared by the Task Force on CCS Costing Methods. 2013. Available online: https:/ / www.globalccsinstitute.com/resources/publications-reports-research/toward-a-co mmon-method-of-cost-estimation-for-co2-capture-and-storage-at-fossil-fuel-power-plants/ (accessed on 15 April 2020).

35. Szima, S.; Nazir, S.M.; Cloete, S.; Amini, S.; Fogarasi, S.; Cormos, A.-M.; Cormos, C.C. Gas switching reforming for flexible power and hydrogen production to balance variable renewables. Renew. Sustain. Energy Rev. 2019, 110, 207-219. [CrossRef]

36. Abad, A.; Adánez, J.; García-Labiano, F.; de Diego, L.F.; Gayán, P.; Celaya, J. Mapping of the range of operational conditions for $\mathrm{Cu}-, \mathrm{Fe}-$, and Ni-based oxygen carriers in chemical-looping combustion. Chem. Eng. Sci. 2007, 62, 533-549. [CrossRef]

37. Abad, A.; Adánez, J.; Cuadrat, A.; García-Labiano, F.; Gayán, P.; de Diego, L.F. Kinetics of redox reactions of ilmenite for chemical-looping combustion. Chem. Eng. Sci. 2011, 66, 689-702. [CrossRef]

38. Gülen, S.C. Gas Turbines for Electric Power Generation; Cambridge University Press: Cambridge, UK, 2019. [CrossRef]

39. IEA. World Energy Outlook. International Energy Agency, 2019. Available online: https://www.iea.org/reports/world-energy -outlook-2019 (accessed on 1 October 2020).

40. Hirth, L.; Ueckerdt, F.; Edenhofer, O. Integration costs revisited-An economic framework for wind and solar variability. Renew. Energy 2015, 74, 925-939. [CrossRef]

41. Khan, M.N.; Chiesa, P.; Cloete, S.; Amini, S. Integration of chemical looping combustion for cost-effective $\mathrm{CO}_{2}$ capture from state-of-the-art natural gas combined cycles. Energy Convers. Manag. X 2020, 7, 100044. [CrossRef]

42. Cloete, S.; Hirth, L. Flexible power and hydrogen production: Finding synergy between CCS and variable renewables. Energy 2020, 192, 116671. [CrossRef] 